Araștırma Makalesi / Research Article

\title{
Cemâlüddin Musa Sâvî/Zilî ve Şeyh Osman-ı Velî ile Ahfadına Dair Vakfiyeler ve Düşündürdükleri (Vahdet-i Tarikat) ${ }^{*}$
}

Vedat Turğut*

(ORCID ID: 0000-0001-7552-4704)

Gönderim Tarihi

(Submitted)

26.07.2020

\author{
Kabul Tarihi \\ (Accepted)
}

31.08.2020

\author{
Yayın Tarihi \\ (Published)
}

30.09 .2020

\section{Atıf Bilgisi/Reference Information}

Chicago: Turğut, V., "Cemâlüddin Musa Sâvî/Zilî ve Şeyh Osman-ı Velî ile Ahfadına Dair Vakfiyeler ve Düşündürdükleri (Vahdet-i Tarikat)", VakanüvisUluslararası Tarih Araştırmaları Dergisi, 5/2 (2020): 1029-1073.

APA: Turğut, V. (2020). Cemâlüddin Musa Sâvî/Zilî ve Şeyh Osman-ı Velî ile Ahfadına Dair Vakfiyeler ve Düşündürdükleri (Vahdet-i Tarikat). VakanüvisUluslararası Tarih Araştırmaları Dergisi, 5 (2) , 1029-1073.

\section{Öz}

Kalenderî Tarikatı́nın kurucusu olarak bilinen Cemâlüddin Sâvî ve onun mürşidi olan Şeyh Osman-ı Velî hakkındaki araştırmaları derinden etkileyecek olan bir vakfiye tespit edilmiştir. Bu vakfiyedeki ifadeler, bizleri Cemâlüddin Sâvî ve Kutbüddin Haydar'ın üzerinden Bayezid-i Bistâmîye ulaştırırken, Ahmed el-Bedevî ve Şeyh Osman-ı Velî üzerinden Ahmed er-Rıfaî ve Abdülkadir-i Geylânî'ye bağlar. Cemâlüddin Sâvî'nin vefatından sonraki dönemlerde "Zilî" olarak kaydedildiği, Karaca Ahmed Menâkıbnâmesi ile tahrir defterlerindeki kayıtlardan, Karaca Ahmed Sultan'ın da bir Kalenderî

\footnotetext{
* Çalışmanın hazırlanması sırasında maddî ve manevî desteklerinden dolayı Bilecik Belediyesi ve VAKAR'a teşekkür ederim.

* Doç. Dr., Bilecik Şeyh Edebali Üniversitesi, Fen-Edebiyat Fakültesi, Tarih Bölümü, Türkiye, vedat.turgut@bilecik.edu.tr.

Assoc. Prof. Dr., Bilecik Şeyh Edebali University, Faculty of Arts And Sciences, Department of History, Turkey.
}

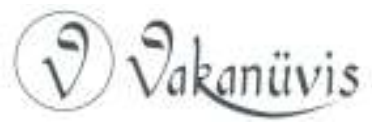


olduğu anlaşılmış ve Karaca Ahmed'in amcası Celalüddin Karatay'ın Sühreverdîliği üzerinden Kalenderiyye ile Sühreverdiyye-Kadîriyye'nin yakınlığı ortaya konulmuştur. Cemâlüddin'in yakın arkadaşı Ebubekir Niksâri yani Şeyh Kalender Baba'nın Mevlana ile yakınlığına binaen Mevlevîliğin de Kalenderilik ile yakın irtibatı müşahede edilir. $\mathrm{Bu}$ bağlamda, özellikle Kalenderiyye/Haydariyye üzerinden dini-tasavvufî yapıların, OrtodoksHeterodoks şeklindeki tasnifine yeniden bir itiraz yapılmış, tasavvuf erbabına yönelik eleştirel yaklaşıma sahip olanların sünnî olarak nitelendirilemeyeceğinin, olsa olsa "taassup" ehli olarak tavsif edilebileceklerinin altı çizilmiştir.

Anahtar Kelimeler: Bistamiyye, Kalenderiyye, Nakşibendiyye, Yeseviyye, Mevleviyye, Bektaşiyye, Karaca Ahmed, Celalüddin Karatay.

\section{The Waqfiyas on Cemaluddin Musa Savi/Zili and Shaikh Osman-i Veli With Their Descendants and on What Those Make Think (United Ways)}

\section{Abstract}

There has been found a waqfiyya, which may alter deeply the studies on Cemâlüddin Sâvî, known to be the founder of Kalenderi order, and his murshid/mentor, Şeyh Osman-ı Veli. The statements in that waqfiyya, take us to Bayezid-i Bistâmî via Cemâlüddin Sâvî and Şeyh Osman-ı Veli. Moreover, it also take us to Ahmed er-Rifaî and Abdulkadir-i Geylânî via Ahmed el-Bedevî and Şeyh Osman-ı Veli. It can be seen that Cemâlüddin Sâvî, after his death, was recorded as "Zilî", that according to Karaca Ahmed's Menakibname and Ottoman Tahrir Defters, Karaca Ahmed Sultan was a Kalenderi derwish, and that via Sührevediyye of Celalüddin Karatay, uncle of Karaca Ahmed, a relationship is shown between Kalenderiyye and Sühreverdiyye-Kadiriyye. By virtue of the relationship between Ebubekir Niksari, that is to say, Shaikh Kalender Baba, who was at the same time Cemâlüddin's close friend, and Mevlana, it is observed that the Mawlawiyya had also a close contact with Kalenderiyye. In this context, especially via Kalenderiyye/Haydariyye, an objection has been made against the classification of religious and sufistic structures as orthodoxy and heterodoxy. And, it should also be emphasized that those who have always critical approaches on sufistic authorities should not be viewed as "sunni", but at the most be seen as "bigotry".

Keywords: Bistamiyye, Kalenderiyye, Nakşibendiyye, Yeseviyye, Mevleviyye, Bektaşiyye, Karaca Ahmed, Celalüddin Karatay. 


\section{Giriş}

Cemâlüddin Sâvi ve Kutbüddin Haydar'ın pirleri bulunduğu Kalenderiyye ve Haydariyye tarikatlarının, pirlerinin birbirleriyle "hiçbir yakınlığı olmaması"na rağmen, tarikatlarının düşünce yapısının tamamen aynı olduğu günümüze kadar ortaya konan çalışmalarda zikredilen en önemli hususlardan biridir ${ }^{1}$. Bu çalışmalara göre, Kalenderiyye'nin piri Cemâlüddin Sâvî, Sünnî bir tarikat şeyhi olan Osman-ı Velî’ye Şam'da intisab etmiş ancak daha sonra Celal Dergezinî adında biriyle arkadaşlık kurarak onun gibi davranmaya başlamış ve bundan dolayı şeyhi tarafından uyarılmışsa da dinlemeyerek onu terketmiş ve Kalenderiyye'yi bir tarikat halinde teşkilatlandırmıştır. Onun Bayezid-i Bistâmî'nin müridi olduğu yönündeki söylemler ise, yaşadıkları dönem arasındaki yaklaşık 350 yıllık süreç göz önüne alınarak reddedilmiştir. Haydariyye'nin kurucusu Kutbüddin Haydar'ın baba adının Şahver ya da Timur bin Ebu Bekir olduğu belirtilmiş ve kendisinin Ahmed Yesevî́nin müridi olarak Hacı Bektaş Velî́nin velâyetnâmesine de konu olduğundan bahsedilmiştir. Hacı Bektaş Velî velâyetnâmesinde Ahmed Yesevî'nin oğlu olarak geçen Haydar'ın da o olduğu düşünülür².

Şeyh Osman-ı Velî́nin Cemâlüddin Sâvî́nin müridi ya da mürşidi olduğu, Mevlana'nın Şam'daki sohbetine Evhadüddin Kirmanî, Şems-i Tebrizî ve Sadrüddin Konevî gibi isimlerle beraber katıldığı bilgisinden

\footnotetext{
${ }^{1}$ Bu araştırmalardan bazıları için bkz. A. Y. Ocak, Osmanlı Imparatorluğu'nda Marjinal Sûfilik: Kalenderiler (XIV-XVII. Yüzyıllar), Ankara 1999, s. 27-30vd; Ocak, Ortaçağlar Anadolu'sunda islam'ın Ayak izleri, Selçuklu Dönemi, İstanbul 2011, s. 80, 84-85, 108, 132-135, 414-415; Ocak, Osmanlı Toplumunda Tasavvuf ve Sûfiler, Ankara 2005, s. 20, 65-66, 72-74, 77-82, 84-86, 180, 183, 188-189, 197, 200, 208-210, 223, 234, 244, 248, 337; Haşim Şahin, Dervişler ve Sufi Çevreler, Klasik Çağ Osmanlı Toplumunda Tasavvufi Şahsiyetler, İstanbul 2017, s. 38, 58, 69, 158, 176, 221-224; Tahsin Yazıcı, "Cemâleddini Sâvî", TDVIA, C. VII, İstanbul 1993, s. 313-314; Yazıcı, "Haydar, Kutbüddin", TDViA, C. XVII, İstanbul 1998, s. 24-25; Osman Turan, "Selçuklu Türkiye'si Din Tarihi'ne Dair Bir Kaynak", Fuad Köprülü Armağanı, İstanbul 1953, s. 553-564; F. Babinger-M. F. Köprülü, Anadolu'da islâmiyet, (Haz. Mehmet Kanar), İstanbul 1996, s. 50, 65, 77; Köprülü, Türk Edebiyatında ilk Mutasavviflar, (Yay. Haz. Orhan Köprülü), Ankara 1976, s. 52-54, 111, 117, 259, 263, 337-339, 351-352.

2 Köprülü, Türk Edebiyatında ilk Mutasavvıflar, s. 52; Yazıcı, "Haydar, Kutbüddin", s. 24; Hünkâr Hacı Bektaş Velî Velâyetnâmesi, (Yay. Haz. H. Duran-D. Gümüşoğlu), Ankara 2010, s. 99-160.
}

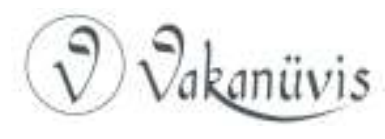


başka hayatı hakkında bilgi bulunmaz. Onun Konya'da bulunan türbesi, Konya'daki Mevlana, Sahib Ata ve Tokat'taki Sevdakâr Murad türbelerine benzetilir ${ }^{3}$. Modern araştırmaların tamamı, Kalenderiyye ve Haydariyye'yi sünnete riayet etmeyen, "heterodoks" bir tarikat şeklinde tanımlamışlardır. Ne var ki, bu araştırmalarda ortaya konan düşünceleri sorgulatan ve sonunda derinden sarsacak nitelikteki bilgileri içeren vakfiyeler, bu çalışmanın ana eksenini belirleyecektir.

\section{Cemâlüddin Sâvi ve Şeyh Osman-ı Velî ile Ahfadı́na Dair Vakfiyeler}

Vakıflar Genel Müdürlüğü Arşivi'nde bulunan H. 655 tarihli "Şeyh Muinüddin Vakfı" başlığı altında kayıtlı vakfiyede, Zile'de Bayezidiyye Hanikâhı adı altında bir hanikâhtan bahsedilir. Bu hanikâhın, H. 655 tarihinden önce de var olduğu, vakfiyenin tarihi dikkate alındığında rahatça anlaşılmaktadır. Vakfiyenin başındaki ayet ve hadisler, vakfiyede adı geçen kişilerin Hanefî Hukuku'nu çok iyi bildiklerini ve benimsediklerini gösterir. Vakfiyede Cemâlüddin Musa'nın Bayezid Bistâmî'nin neslinden olduğu sarihen bildirilir. Vakfiyeden Şeyh Cemâlüddin'in Şam'ın Salihiyye adı verilen muhitinde Şeyh Osman-ı Velî̀ye intisab ettiğine dair bilgiyi teyid etmek mümkündür. Asıl adının Musa olduğu anlaşılan "Ariflerin Sultanı, Velîlerin Kutbu" Cemâlüddin'in Horasan/Sâve'de doğduğu ve Tokat'a bağlı Zile'de vefat ettiği açıkça beyan edilir. Onun Kırıkhan'da medfûn bulunan İsa adında bir kardeşinin olduğu da bilinir. Cemâlüddin Musa'nın Bayezid ve Ali adlarında oğullarının olduğu da vakıf belgesinden anlaşılır ${ }^{4}$.

Oğlunun ve atasının adıyla anılan hânikahta, Şeyh Muhiyiddin Osman-ı Velî́nin oğlu Şeyh Ali el-Mücerred'den olma torunu Şeyh Muinüddin Halil Zilî, Bistâmiyye tarikinden bir hanikâh bina etmiştir. Mücerred, tasavvufta sâlikin dünya ve ahiret nimetlerini bir yana bırakıp Allah'a yönelerek sadece O'na gönül vermesi anlamındadır ${ }^{5}$. Şeyh Ali, "el-mücerred" sıfatına uygun olarak ayrıca "samedâni/hiçbir şeye muhtaç olmayan" şeklinde de vasıflandırılır. Osman-ı Velî́nin oğlunun "mücerred" sıfatı ile anılmasının üzerinde hassaten

\footnotetext{
${ }^{3}$ Hakkı Önkal, "Üç Selçuklu Türbesi Hakkında Notlar", Dokuz Eylül Üniversitesi, ilahiyat Fakültesi Dergisi, II, İzmir 1985, s. 39.

${ }^{4}$ VGMA, D. 1966 , s. $1 / 1$.

${ }^{5}$ Süleyman Uludağ, "Mücerred", TDViA, C. 31, İstanbul 2006, s. 447-448.
}

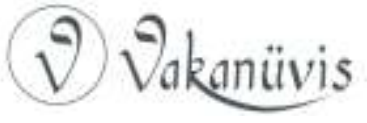


durulmalıdır. Burada mücerred, "çıplak, tek başına yaşayan" manasına gelmektedir. Buradan Osman-ı Velî’nin oğlunun "kalendermeşreb" bir inziva halinde yaşadığını anlamak mümkündür. Ancak, buradaki "kalendermeşreb" tavsifi, 20. Yüzyıla ait tanımlamalardan berîdir.

"Seyfullah" ve "Nurullah" sıfatlarıyla da anılan Muinüddin Halil, vakfın tevliyetini oğlu Şeyh (ibrahim) Edhem'e şart etmiştir. Muinüddin Halil'in vekili, Şeyh Osman-ı Velînnin kardeşi Şeyh Hasan Dede'nin oğlu Şeyh Rüknüddin'den olan torunu Mevlana Nasırüddin'dir. Vakfın şahitleri arasında zikredilen Ali oğlu Tacüddin Hasan, Cemâlüddin Musa'nın torunu olmalıdır. Şeyh Muinüddin Halil, Zile'deki altı kıt'a arz ve altı adet bahçesini ${ }^{6}$ "vakf-ı sahih-i şer'i ve habs-i sarih-i mer'i" ile Bayezidiyye Hanikâhı'na vakfetmiştir?.

"Kutbü'l-Meşâyih Cemâlüddin Musa" tarafından Zile'nin merkezinde, "Müslüman fukara ve tevhide gönülden bağlı miskinlere" mahsus olmak üzere bina edilen zaviyede, "taliblerden" olmayanların üç gün, hanikâhtaki tasavvuf ruhuna bağlanıp hizmet etmek isteyenlerin ise istedikleri kadar ikâmet edebileceklerinin vakıf şartları arasında yer aldığı görülür. Vakıf binasının tamir edilemeyecek kadar harab olması durumunda vakıflardan elde edilen hâsılın Medine fukarasına gönderilmesi istenmiştir8.

Tokat'ın Kızlar Köyü’nde “Ahmed el-Bedevî”nin oğlu "Şemsüddin Ahmed"in oğlu Muinüddin Âdil'den olan torunu Ali tarafından $\mathrm{H}$.

\footnotetext{
${ }^{6}$ Vakfedilen altı kıt'a arzdan biri Bucakpare namında ve mahallî kile ile on kile buğday tohumunu alabilen ve sınırları muayyen buğday tarlasıdır. İkincisi Dudaş namında ve mezkur kile ile 15 kile buğday tohumunu alabilen bir yer olup, Dudaş Köprüsü'nün yanında yer alır. Üçüncüsü, Kepektarla adında 12 kile buğday tohumunu alabilen yer olup, bir sınırında Kızılcakaresi Köprüsü yer alır. Dördüncüsü Tefrik kıt'ası namında 15 kile buğday tohumunu alabilen bir yer olup, Tokat'a giden yoldan başlayıp, Turhal'a giden yola kadar uzanır. Beşincisi Halepte adında beş kile buğday tohumunu alabilen bir yer olup, sınırında nehir ve Celebpınarı bulunur. Altıncısı Darıcı adında 12 kile buğday tohumunu alabilen bir yer olup, Darıcı Nehri'ne yakındır. Altı adet bahçenin ise Çatalsokak nam mevkî'de olup, içlerinde 500 amele tarafından işlenen bahçelerin olduğu, doğusundan ve batısından yolların geçtiği halde kuzeye doğru uzanmaktaydılar.

${ }^{7}$ Bu vakfın muteber olduğuna Şeyh Razıyüddin b. Şeyh Yahya b. Şeyh Safiyüddin, Şeyh Nizamüddin Receb b. Şeyh Nu'man ve Receb Çelebi b. Hasan Bey b. Ataullah şehadet etmişlerdir.
}

8 VGMA, D. 1966 , s. $1 / 1$

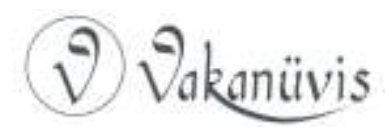


Rebiülahir 789 'da kurulan zaviye vakfı da konumuz açısından oldukça önemlidir. Ahmed er-Rıfâînnin tarikinden olan Bedevî'nin evlâdının, Bayezîdiyye/Kalenderiyye tarikinden ve Abdülkadir-i Geylânî'nin torunlarından olan Ali el-Mücerred'in evlâdı ile evlilik teşkili suretiyle akrabalık tesis etmesi, Kalenderiyye'nin nasıl bir tarikat olduğunun anlaşılabilmesini sağlayacaktır. Bu vakfiyede vâkıf, "âbidlerin ve zâhidlerin seyyidi" olarak tavsif edilir ${ }^{9}$. Vakfiyede adı geçen şahitlerden Şeyh İlig ve evladının adına, aynı zaviye ile ilgili diğer vakfiyelerde de rastlanır. Onun kendi adına Zile'de kurduğu bir zaviyesi de vardır. Hacı Bayezid bin Velid-i Bektaşî’nin ise, Bektaşî tarikinden olduğunu ve Bektaşîliğin de Bayezidiyye'nin bir kolu olduğunu söylemek mümkündür. Hasan Bey'in babası Kutlu Bey'in ise, Amasya'da emirlik yapan Kutlu Bey/Paşa olması gerekir. Vakıf belgesinden, Zile'ye bağlı Kızlar Köyü'nde de "şeyhlerin ve âriflerin ulusu" Şeyh Edhem ve evladının tevliyetine meşrût bir zaviye bina edildiği anlaşılır. Zaviye için köyün tamamı vakfedilmiştir. Zaviyenin tamir edilemeyecek kadar harab duruma düşmesi durumunda köyün hâsılının Zile'deki zaviyeye gönderilmesi şarta bağlanmıştır. Tahrir defterlerine bakıldığında Kızlar Köyü’nün diğer hissesinin; Ahi Evren, Yağmur, Eyüge, İstolos, Haris, Gezerbey, Kulaca, Kurşunlu ve Ermeni köyleriyle beraber, Ahi Evren adına Tokat'ta bina edilen zaviyeye vakfedilmiş olduğu müşahede edilir ${ }^{10}$.

Yukarıda adı geçen Şemsüddin Ahmed, Ahmed el-Bedevî̀nin evlâdındandır. Onun, Şeyh Alaüddin Ali el-Mücerred'in oğlu Şeyh Muinüddin Halil'in kızkardeşi ve Şeyh Edhem'in halası olan Fatma Hatun ile evli olduğu, H. 10 Rebiülevvel 701 tarihli vakfiyeden anlaşılmaktadır. Bu vakfiyede vâkıf, "meşahir ve akranın seyyidi, kabail ve a'yanın mefahiri merhûm Bedevizâde Şemsüddin Ahmed" şeklinde tavsif edilir. Vâkıf ve eşi Zile'ye bağıı Belkayası/Belkayı adlı köyün yarı hissesini, eşi Fatma Hatun ile beraber vakfetmiştir. Köyün hududu, Kızlar Köyü ile Araplar, Güngörmez ve Hisarcık köyleriyle müntehîdir ${ }^{11}$.

\footnotetext{
9 VGMA, D. 1966, s. 2/2. Vakfiyede şahitlerin isimleri ise şu şekilde verilmiştir: "Şeyhlerin ve âriflerin mefahiri Şeyh illig b. merhûm Şeyh Bayram, Seyyidü'l-eimme Mehmed b. merhûm Süleyman, İsmail b. Kutbüddin, Hacı Bayezid b. merhûm Velid Bektaşî, Esad b. İvaz, Hasan b. Kutlu Bey ve Günci b. Ali Baluce

10 TADB. TTD. EV. 583, v. 34a.

11 VGMA, D. 1966 , s. $3 / 4$.
}

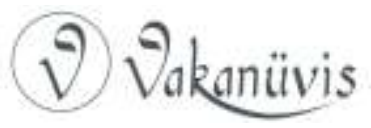


Burada adı geçen Fatma Hatun'un Hacı Bektaş Velî́nin el verdiği Fatma Bacı olma ihtimali oldukça fazladır. Şeyh Osman-ı Velî́nin torunu olan Fatma Hatun da Ahi Evren'in eşi Fatma Hatun gibi Hacı Bektaş Velî'nin çevresinde bulunan bacılardandı. Bölgede Abdal Musa adına bir makamın olması, Hacı Bektaş Velî’nin el verdiği/ihtiyar ettiği Fatma Bacı'nın Ali el-Mücerred'in kızı olan Fatma Bacı olduğu fikrini kuvvetlendirir ki Abdal Musa da Cemâlüddin Musa'nın torunlarından olmalıdır. Yukarıda da değinildiği üzere, Yeseviyye'ye bağlanan Kalenderiyye/Haydariyye ve Bektaşiyye'nin esasen Bayezidiyye'nin birer kolları olduğu, vakıf belgesinden anlaşılır. Hacı Bektaş Velî́nin Ahmed Yesevî'nin nefes evladından olan Haydar Baba ile ilgili kıssası burada bir daha hatırlanmalıdır.

Tokat'a bağlı Zile'deki Şeyh Cemâlüddin Musa Zaviyesi'ne "Ahi Mine'r-resûl" tarafından Pilafî Köyü'nün vakfedildiği de H. Receb 707 tarihli vakfiyeden öğrenilmektedir. Burada Şeyh Musa, "meşâyihin sultanı ve evtâdın kutbu, salih şeyh" şeklinde tavsif edilirken, Kabertu oğlu Ahi Minerresûl, "erbâb-ı fütüvvet ve mürüvvet" şeklinde kayıtlıdır. Ahi'nin asıl adını tespit etmek mümkün olmasa da seyyidlerden olduğu bellidir. Şeyh Musa hakkında da kutbü'l-evtad tâbîrinin kullanılması ${ }^{12}$, Şernûbî tarafından isimleri zikredilen dört kutuptan başka kutuplar olduğunu da göstermektedir ki bu dört kutup; Seyyid Abdülkadir-i Geylanî, Ahmed er-Rıfâî ve bu ikincisine bağlı olan İbrahim Dessûkî ile Ahmed el-Bedevî'dir ${ }^{13}$.

Zile'nin merkezinde bulunan zaviye'nin mesâlihi için "Aytemür oğlu merhum Emir Hüseyin'in oğlu Ahi Ali"nin de H. Şaban 708 tarihinde Devecisaray Köyü'nün beşte bir hissesini vakfettiği görülür. Vakfın tevliyetini "taliblerin mürşidi ve Âşıkların enisi Şeyh Edhem"e ve evlâdına şart kılan Ahi Ali'nin, Allah'ın "Hayy", "Halim", "Cevad" ve "Kerim" isimlerine sığındığı kayıtlıdır ${ }^{14}$.

Bayezidiyye Hanikâhı için ümeradan Emirzâde Melik Yakubşah b. (Sinanüddin) Yusuf Şah da H. 801 tarihinde Zile'ye bağlı Hacılar Köyü’nü vakfetmiştir. Bu köyün hududunun, Kızılcaköy, Kurşunlu,

\footnotetext{
12 VGMA, D. 1966, s. $3 / 3$.

13 Derya Çakır Baş, "Bedeviyye", Türkiye'de Tarikatlar, Tarih ve Kültür, (Ed. Semih Ceyhan), İstanbul 2015, s. 547-608.

${ }^{14}$ VGMA, D. 1966 , s. $3 / 5$.
}

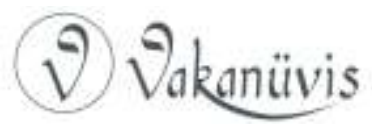


Bağluca ve Karaöyük köyleriyle çevrili olduğu belirtilmektedir. Vakfiyede vâkıf, "umera ve e'azim sülâlesinden cengâverlikle meşhur, muharebe yerlerinin arslanı" şeklinde tavsif edilir. Bu kişinin yukarıda anılan Aytemür oğlu Emir Hüseyin'in soyundan geldiğini tahmin etmek zor değildir. Vakfın tevliyeti ve nezâreti, "âbid ve zahid ve müttaki" Şeyh Edhem b. Şeyh Muinüddin'e ve evlâdına şart edilmiştir. Vakfın şahitleri arasında Şeyh illig oğlu illyas'ın yer alması, yukarıda da değinildiği üzere bu ailenin Bayezidiyye Tarikatı ile olan güçlü bağlarına işaret eder. İlig isminin, Bektaş ismi gibi Karahanlı asilleri tarafından sıklıkla kullanıldığı da burada hatırlanmalıdır ${ }^{15}$.

Amasyalı Ali Çavuş b. Yahya da mezkûr hanikâh için vakıf yapanlar arasında yer alır. Onun H. Zilkâde 969 tarihinde tertip ettiği vakfiyeye göre, Ayvalı Nahiyesi'ndeki Kızılkünbet Köyü'nde Ayvalı değirmeni ve Cihanşah adıyla ma'ruf malikânenin yarısı, zaviyenin masraflarına vakfedilmiştir. Vakfın tevliyet ve nezâreti ise, "kulların mefahiri, aşıkların enisi" Şeyh Abdülkerim b. Şeyh Muinüddin'e ve evladına şart edilmiştir ${ }^{16}$. Buradaki kayıttan, zaviyenin XVI. yüzyılın sonlarına kadar, Şeyh Muinüddin Halil'in torunları tarafından tasarruf edilmeye devam edildiği anlaşılmaktadır.

Tokat'a bağlı Zile ve Niksar'da bulunan kalenderhanelere dair tahrir defterlerinde bulunan kayıtlara bakıldığında tarihi değeri çok önemli olan bu bilgileri daha iyi değerlendirme imkânına sahip olunabilir. Muinüddin Halil tarafından Bayezidiyye Hanikâhı içinde toplanan bir mecliste akdedilen vakfiyeye göre kurulan vakıf, tahrir defterine "Edhem Çelebi Zaviyesi ve Mescidi" şeklinde kaydedilmiştir. Zile'de iki çiftlik, bir değirmen, bağlar, Balalı ve Korucak köyleri ile Sancar mezra'ası, Yenimüslüman'a bağlı Tilfani, Kızılkünbed'e bağlı Deveci'nin beşte bir hissesi, Ayvalu'nun yarı hissesi, Meşhed'e bağlı Kavacık Köyü ve Kırlar mezra'ası, Kazabad'a bağlı Güldikilen Köyü, Şadi Bey değirmeni ve Zile'deki Köhne Hamam'dan hâsıl olan 1500 akçeyle beraber, vakfın toplam gelirinin 19.500 akçeye yakın olduğu hesaplanmıştır. Zaviyenin meşihât ve nezaretinin evlatlık üzere

\footnotetext{
15 VGMA, D. 1966, s. 4/6. Vakfiyenin şahitleri, Kastamonulu Hasan b. Zekeriya, Ahmed b. Yahya Kafhafi, Davud b. İsmail, Emir Hasan b. İmad Kafhafi ve Illyas b. Şeyh ilig şeklinde sıralanır.
}

${ }^{16}$ VGMA, D. 1966 , s. 4/7.

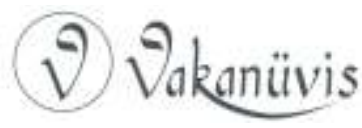


"fahrü's-sâlihîn Şeyh Abdülkerim"in üzerinde olduğu bu defterden de te'yid edilir ${ }^{17}$.

Vakfiyeden Şeyh Edhem'in Osman-ı Velî́nin torunu olduğu açıkça anlaşılmasına rağmen, yerel rivâyetler onun Horasan erenlerinden Nasırüddün Musa Fakih'in torunu olduğunu belirtir. Hanikâhın vakfiyesinin, Cemâlüddin Musa'nın "Bayezid Tayfur bin İsa” adına kurduğu hanikâhta tertip edildiği açıkça belirtilir. Bu durumda Cemâlüddin Musa'nın zaviyesinin başka bir zaviye olduğunu düşünmek mümkündür. Zile'ye 7 km uzaklıktaki Şeyh Nusret/Aksaray Köyü'nde bulunan ve günümüzde sadece camisi ve türbesi ayakta kalabilen Şeyh Nusret Türbesi'nin de Osman-i Rumî'nin kardeşi Hasan Dede'nin torunu olan Şeyh Nasrüddin'e ait olduğunu düşünmek mümkündür. Bu kişinin adının, Muinüddin Halil'in oğlu Şeyh Edhem'in zaviye vakfında zikredilmesi, bu düşüncenin sebebini teşkil eder. Şeyh Nusret'in yerel rivayette Edhem Çelebi'nin dedesi Nasırüddin Musa'ya dönüştüğü düşünülebilir. Bununla beraber Halit Çal, Şeyh Nusret adına tertip edilen H. 754/M. 1353, H. 770/M. 1368 ve H. 792/M. 1389 tarihli üç vakfiyede, şeyhin tam isminin "Şeyh Nusret b. Hamza" şeklinde kayıtlı olduğunu belirtir. Türbenin hemen dışındaki mezarın, Şeyh Nusret'in babası Hamza'ya ait olduğu rivâyeti vardır. Şeyh Edhem'in türbesinde Şeyh Nasrüddin Musa adına bir sandukanın varlığı, köydeki türbenin Cemalüddin/Nasrüddin Musa'ya ait olabileceğini de düşündürür. Onun baba adının Hamza olması da akla Kutbüddin Haydar'ı getirir ki bilindiği üzere Haydar, "sürüsüne liderlik eden lider Aslan" manasında olup, $\mathrm{Hz}$. Hamza da "Allah'ın aslanı" şeklinde şöhret bulmuştur. Dolayısıyla Cemalüddin Nasrüddin Musa'nın babası, Kutbüdddin Haydar Hamza olabilir. Bununla beraber, vakfiyede adı geçen Hasan Dede'nin oğlu Rüknüddin'in asıl adının Hamza olabileceğini söylemek de mümkündür. Şeyh Edhem'in annesinin, Şeyh Nusret'in kızı olduğu kanaati vardır. Nusret Şeyh Zaviyesi'nin bir kalenderhane zaviyesi olduğu bilinir.

H. 1272/M. 1855'te Dedezâde Hüseyin Ağa tarafından ta'mir ettirilen Şeyh Nusret Türbesi'nin içinde kalemişi çok nadide çizimler dikkati çeker. Duvarlardaki çizimleri Arapzâde Emin Usta, H. 1275/M. 1858 'de yapmıştır. Arapzâde unvanını, Bedevîzâde Şemsüddin Ahmed ile ilişkilendirmek mümkündür. Halit Çal, bu tarz duvar resimlerinin,

${ }^{17}$ TADB. TTD. EV. 583, v. 46a-47b.

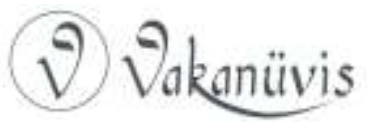


XVIII. yüzyıldan geriye gitmediğinin altını çizer ${ }^{18}$. Dolayısıyla Söğüt'te bulunan İsa Sofu Türbesi'ndeki kalemişi çizimlerin de sonradan yapıldığı aşikâr olup, İsa Sofu'nun şaman özelliklerini koruyan bir Türkmen babası olduğu yönündeki iddiaları kabul etmek mümkün değildir ${ }^{19}$. İsa Sofu'nun da Osman Gazi dönemi Bistâmî-Kalenderî şeyhlerinden biri olduğu söylenebilir. Şeyh Nusret Türbesi'nin tek kubbe ile örtülü baldakeni içinde, sağ ucunda sarığı olan büyük bir sanduka görülür. Kubbeye bağlı zincirden bir fener sarkmakta olup, fenerle sanduka arasında "Seyyid Ahmed Rıfâî Sırrıhe'l-abdi/aziz" yazılıdır. Türbe içindeki üç sandukada Şeyh Nasrüddün'den başka onun soyundan gelen Abdülhannan oğlu Seyyid Mehmed ve kızı Siret Hatun yatar. Şeyh Nusret'in soyundan gelenlerin XIV. yüzyılda bölgedeki nüfuzlarını korudukları, beylikler arası diplomaside üstlendikleri rollerle sabittir $^{20}$. Şeyh Nusret Zaviyesi'nin 20.000 akçeyi bulan geliri, zaviyenin ne kadar önemli bir kalenderhane olduğu hakkında bir fikir verir. Tahrir defterlerine göre de zaviye için zaviyenin bulunduğu Aksaray Köyü’nün yanısıra Karagazi, Bağdadhisarı, Belhıs, Karaöyük, Savcı, Acıpınar, İsa ve Amasya'daki Şıhlar köyleri ile Çukruk mezra'asının vakfedildiği görülür. Zaviyenin tevliyet, nezâret ve meşihâti evlattan Abdülhannan, Kalender, Kılıç, Salih, Pir Ayan ve Yakub'un tasarrufundadır ${ }^{21}$.

Cemâlüddin Musa'nın müridlerinden Ömer Çelebi'nin kurduğu zaviyeye dair vakıflar da tahrir defterinde bulunur. Yerel rivâyetlere göre, Şeyh Edhem onun kızı Ümmügülsüm ile evlenmiştir. Bu rivâyetleri, türbe içindeki sandukaların üzerlerindeki plakalardan da takip etmek mümkündür. Zile merkezinde "Kalenderhâne" Zaviyesi adı altında ayrıca bir vakıf daha vardır. Bu zaviyenin Sulugöl ve Çarıkbağı mezra'alarının $1 / 3$ ve buradaki bağların yarı hissesini tasarruf ettiği görülür. Yukarıda ele alınan vakfiyelerde şahit olarak adına rastlanan Şeyh İlig'in de Kavacık Köyü’nde bir kalenderhane zaviyesi bina ettirdiği

18 Halit Çal, "Şeyh Nasreddin (Nusret) Türbesi", Türk Tarihinde ve Kültüründe Tokat Sempozyumu (2-6 Temmuz 1986), Bildiriler, Ankara 1987, s. 427-461.

${ }^{19}$ Nurfeddin Kahraman vd., "Isa Sofu Türbesi: Tezyinatı ve Türklerin İslamlaşma Süreci Açısından Değerlendirilmesi”, Türk Kültürü İncelemeleri Dergisi, S. 41, (Bahar 2019), s. 121-154.

20 Çal, "Şeyh Nasreddin (Nusret) Türbesi", s. 427-461; Yaşar Yücel, Kadı Burhaneddin Ahmed ve Devleti (1344-1398), Ankara 1970, s. 84.

${ }^{21}$ TADB. TTD. EV. 583, v. 48a-b.

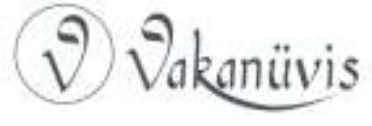


anlaşııır. Vakıf evladından Kalender, Muhammed, ilig, Budak ve Çırak adındaki beş kişi zaviyeyi tasarruf etmekteydiler. "ilig" ismi de "Bektaş" gibi Karahanlı hanedanı tarafından kullanılmakta olduğundan, "hükümdar ailesine mensup olan" manasına geldiği gibi, "kardeş" ve "iplik bükmeye yarayan araç" manlarına da gelir. Anadolu'da "Örgücü Baba" olarak bilinen kişi ile bir bağlantısı olduğu da düşünülebilir. Cemâlüddin Musa'nın müridlerinden Mübarek Şah'ın da Konya'ya gitmeden evvel, Niksar'da bir zaviye ve mescid bina ettirdiği anlaşılır. Niksar'a bağlı Huri Köyü'ndeki bazı zemin mescidin mesâlihine vakıftır. Yukarıda vakfiyesi hakkında bilgi verilen Yusuf Şah'ın bina ettirdiği mescid için de Eyrekderesi mezra'ası vakfedilmiştir. Bundan başka "Kalenderhane Mescidi" olarak kaydedilen mabede de burada değinilmelidir. Şeyh Yakub, Emirci Doğan ve Seydi Alişir, Karabıyık zaviyeleri gibi pek çok zaviyenin Bistamiyye tarikatına bağlı oldukları görülür22.

Tahrirlerde kayıtlı en önemli Üveysî-Bistâmî-Kalenderî karakterlerden biri, şüphesiz Emirce Sultan'dır. Emirce Sultan gibi Üveysîmeşrep bir karakter ortaya koyan pek çok sufî bulunur ki bunlar; ibrahim b. Edhem, Bayezid-i Bistamî, Ebu'l-Hasan Harakanî, Ebu'lKasım Cürcanî, Bahaüddin Muhammed Nakşibendî ve Mahmud Hayranî'dir ${ }^{23}$. Bunlardan İbrahim bin Edhem'in üveysîliği, hakkında söylenen "gaipten gelen bir sesle uyarıldığı için 'murad' vasfına sahip olan sûfilerden" şeklindeki ifadeden anlaşılır24. Emirce Sultan İsmail ile Kutbüddin Haydar/Cemâlüddin Musa'nın da Bistamiyye müridleri olarak aynı aileye mensub oldukları anlaşııır. Emirce Sultan adına kayıtlı köylerden birinin adı Şeyh Musa olup, Kalenderîliğin kurucusu Cemâlüddin Musa'dan mülhem olmalıdır. Emirce Sultan hakkında teferruatlı bir çalışma kaleme alan Ahmet Yaşar Ocak, Emirce Sultan'ın asıl adının Şerefüddin İsmail b. Muhammed Arabşah olduğunu ve Emirce Sultan'ın Hızır Paşa ve illyas Paşa adında iki de kardeşinin tespit edildiğini belirtir. Bunlardan Hızır Paşa'nın oğlu olan Osman Paşa'nın, vakfın yöneticilerinden biri ve Şerefüddin İsmail'in halefi olması hasebiyle Emirce Sultan ile karıştırıldığı da bu çalışma ile ortaya

\footnotetext{
22 TADB. TTD. EV. 583, v. 47b, 49b, 52b, 54b.

${ }^{23}$ Necdet Tosun, "Üveysilik", TDVIA, C. XLII, İstanbul 2012, s. 400-401.

${ }^{24}$ Reşat Öngören, "ibrahim b. Edhem”, TDVIA, C. XXI, İstanbul 2000, s. 293-295.
}

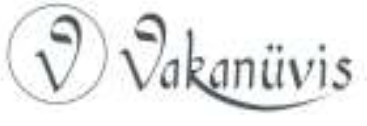


konulmuştur. Emirce Sultan'ın Saadet Hatun adında bir de halası vardı. Osmanlıların ataları gibi Üveysî bir tasavvuf karakteri olan Emirce Sultan'ın, Ahmed Yesevî́nin halifelerinden olduğu belirtilir. Onun oğullarından biri olduğu anlaşılan Ahmed Bican'ın Çorum'da vakıfları olan Hıdır(lık) Sultan olduğu tahmin edilir ${ }^{25}$.

Emirce Sultan'ın Alaüddin Keykubad ve oğlu Keyhüsrev dönemlerinde yaşadığı bilinmekte ise de Tokat/Niksar'da bulunan zaviyeye dair tahrir kayıtlarında zaviyenin, Melik Danişmend Gazi devrinden beri Emirci evladı tarafından tasarruf edildiğine dair bilgi ${ }^{26}$, bu konuda ileri sürülen alternatif rivâyetin, tahrir eminlerinin kalemine yansıdığını gösterir. Emirce Sultan'ın, amcası Hızır Paşa ile beraber, Babaî İsyanı sırasında şehid düştükleri düşünülür. Emirce Sultan ile aynı aileden olan Hızır ve İlyas Paşa ile Seyyid Ali ve Tur Ali Baba, Emirce'nin müridleri arasında yer alır. Bunlardan başka, Bektaşî ve Mevlevî kaynaklarında da adına rastlanan Hoca Ahmed Fakih de Emirce'nin müridleri arasında zikredilir. Emirce Sultan Zaviyesi başlığı altında tahrir ve vakfiye kayıtlarına yansıyan bilgiler, zaviyenin çok zengin akarata sahip olduğunu gösteririr7. Kastamonu'da "Sultan Emre Bey" adına kurulan zaviyenin de Emirce Sultan, Tapduk Emre ya da Yunus Emre namına tesis edildiğini söylemek mümkündür ${ }^{28}$. Sultan Orhan zamanında, Kocaili Sancağı dahilinde "Emirce Sultan" adına kurulan vakıf dolayısıyla Şerefüddin İsmail'in soyu hakkında bilgi bulmak mümkün olmuştur. Buna göre, Emirce Sultan'ın Yakub Bey adındaki oğlundan Hızır ve illyas adında iki torunu olmuş ve Hızır'ın Beytullah Dede, ilyas'ın ise Mustafa Dede ve Derviş adında çocukları olmuştur ${ }^{29}$.

25 A. Yaşar Ocak, "Emirci Sultan ve Zaviyesi, XIII. Yüzyılın İlk Yarısında Anadolu (Bozok)'da Bir Babaî Şeyhi: Şerefüddin İsmail b. Muhammed", İstanbul Üniversitesi Edebiyat Fakültesi, Tarih Enstitüsü Dergisi, S. 9 (1978), s. 136-137, 141-142, 146-147, 149, 151-158, 161, 181-192.

26 TADB. TTD. EV. 583, v. 61a.

27 Ocak, "Emirci Sultan ve Zaviyesi...", s. 136-137, 141-142, 146-147, 149, 151-158, 161 , 181-192. Burada kayıtlı bazı mezârinin "Dedigi" Köyü halkı tarafından ziraat edildiği belirtilir. Bilindiği üzere Anadolu'nun pek çok yerinde "Dedigi Sultan" adında bir şeyh adına kurulan zaviyeler bulunur. TADB. TTD. EV. 583, v. 59b-61a.

28 TADB. TTD. EV. 554, v. 65a.

${ }^{29}$ TADB. TTD. EV. 579, v. 59b-61a.

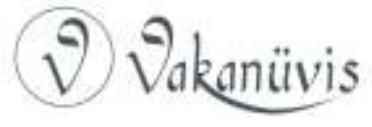


Bursa'daki Mısırşah mezrâ'sının da Veysel Karanî soyundan geldiği belirtilen Halil Baba'ya vakfedildiği hatırlanmalıdır ${ }^{30}$.

Osmanlıların ve Batı Anadolu beyliklerini kuranların atası olan Şeyh Nu'man'ın yâni Dede Karkın'ın esas adının Sultan İsmail olduğu ${ }^{31}$ ve Yunus Emre ${ }^{32}$ ile İznik'te bir mescidi bulunan Hacı Hamza'nın atası Erdemşah'ın baba/dede isimlerinin de İsmail olduğu burada hatırlanmalıdır ${ }^{33}$. Bu husus, bir başka çalışmamızda "Renklerin Efendileri" adlı çalışmada tafsilatıyla ele alınacağından burada ayrıntıya girilmeyecektir. Hatay Kırıkhan'da Bayezid-i Bistamî makamı olarak bilinen türbenin ise, Cemâlüddin Musa'nın İsa adındaki kardeşine ait olduğu yöre halkı tarafından kabul edilmiş rivâyetlerdendir.

Mahmud Çelebi b. Celâlüddin Emir Mahmud b. Sadr-ı Şehid Sinanüddin $b$. Emir Yusuf Çelebi $b$. Nizamüddin Abdullah Çelebi $b$. Bedrüddin Mahmud'un, H. 841 tarihli vakfı ${ }^{34}$ ile "Celâlüddin Mehmed b.

30 TADB. TTD. EV. 580, v. 13a.

${ }^{31}$ Haşim Şahin, "Selçuklu ve Erken Osmanlı Döneminde Vefâiyye Tarikatı", Türk Kültürü ve Hacı Bektaş Veli Araştırmaları Dergisi, S. 70 (2014), s. 39-54.

32 Ö. Lütfi Barkan, "Osmanlı İmparatorluğu'nda Bir İskân ve Kolonizasyon Metodu Olarak Vakıflar ve Temlikler I: İstilâ Devirlerinin Kolonizatör Türk Dervişleri ve Zâviyeler", Vakıflar Dergisi, II (1942), s. 295, 296, 335, 385.

${ }^{33}$ Semavi Eyice, "Hacı Hamza Bey Mescidi ve Türbesi", TDVIA, C. XIV, İstanbul 1996, s. 479; E. Hakkı Ayverdi, "Orhan Gazi Devrinde Mimari", Ankara Üniversitesi Ilahiyat Fakültesi Yıllık Araştırmalar Dergisi, I, Ankara 1956, s. 121; Ayverdi, Osmanlı Mimarisinin ilk Devri, İstanbul 1966, s. 162; i. Hakkı Konyalı, Abideleri ve Kitabeleri ile Konya Tarihi, Konya 1964, s. 354; Mehmet Önder, Mevlana Şehri Konya, İstanbul 1971, s. 125; Remzi Duran, Selçuklu Devri Konya Yapı Kitabeleri (İnşa ve Ta'mir), Ankara 2001, s. 70-71.

${ }^{34}$ VGMA, D. 733 , s. 58/28. Mahmud Çelebi, Tokat'ta bir kaç yazlık oda ile kışık odayı ve bunlara bitişik mahzenleri müştemil ev ile müstakil avlusunu ve içindeki hizmetçileri, uşakları, odaları ve hücreleri, askerî koğuşları ve ahurları ile birlikte eve muttasıl diğer avlusunu vakfetmiştir. Emir Hüsamüddin b. Emir Hüseyin Çelebi b. mezkûr Emir Yusuf'un birleştirdiği, içindeki mengenehane ve bu mengenehanede gömülü küpleri ile birlikte birbirine muttasıl üç bahçe yeri de akarat arasındadır. Çağa Gölü mevkiinde, Çelebi Sultan Mehmed'in vâlidesi Devlet Hatun'un Hasbağ adıyla ma'ruf bahçesine sınır olan bir arz da vakfa aittir. Buğdaypazarı kurbundaki yukarı ve aşağı değirmenin ortasında bulunan iki gözlü orta değirmen, Hasanâbad namındaki mezreası ile beraber Kavakköyü, Karaulu Köyü, Zile'de Donuzlu Köyü'nün 3/4 sehmi, Üçtaş'a bağlı Arslangazi Köyü, Hasaneri Köyü'nün 7/9 hissesi, Halil Kûhî Köyü, Sakaluk Köyü, Artukâbad'a bağlı Mansurköy'ün yarı hissesi, Yıldızköy, Şaniköy, Kızoğlu Köyü, Alayundlar Köyü ile Sivas tevâbîinde Derbend Köyü hanikâha vakıftır. Vakfiyede, vâkıfın

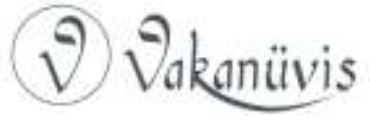


Sadr-ı merhûm Nizamüddin Emir Yusuf b. Sadr-ı Said Izzüddin Musa elKettani"nin kurduğu H. 764 tarihli vakfı da Bayezidiyye Hanikâhı etrafında değerlendirilmelidir ${ }^{35}$. Söz konusu belgelerde, ilk dönem Osmanlı veziriazamları arasında yer aldığı anlaşılan "sadr-ı şehid" Sinanüddin Yusuf Paşa ${ }^{36}$ adının geçmesi önemlidir. Fetret devri baş vezirlerinden Haydar/Hamza oğlu İmamzâde Hızır Halil Danişmend ${ }^{37}$ ile oğlu Koca Nizamüddin Mehmed Paşa ${ }^{38}$ ve Aykut Alp'in torunu Kara

aile bireylerine ait türbeler hakkında da bilgi bulunur. Bunlardan biri, Sivas'taki Şemsüddin Ahmed Zaviyesi'ne muttasıl Ahi Hasan Ahmedî'nin zaviyesine yakın bir yerdedir. Diğeri, Pelidkuyu Kabristanı'nda vâkıfın bazı oğulları ile anasının ve ninelerinin akrabalarının medfûn bulunduğu türbedir. Üçüncüsü, Tokat'ta Erenlerdağı hizasındaki Kalenderhane zaviyesinin avlusunda olup, vâkıfın bazı evladı ve amcası Emir Hüseyin'in ve evlâdının türbeleridir.

35 VGMA, D. 582/1, s. 20/11. Bu hânikâh için Kazabad'a tâbi Karanî Köyü, Tada Köyü'nün 3/4'ü, Karauluturhal Köyü’nün 12 sehimden 11 sehmi, Mendas Köyü'nün yarısı, Kemaliye Köyü, Kırıdkasan arazisinden müfrez bir arz, Kürdler mezra'sı, Eymür Köyü, Çay ve Kasan köyleri, Meşhedabad'a tâbi Çubuk Köyü, Hisarcık Köyü, Meşhedabad Köyü'nün 3/4'ü, Artukabad'a tâbi Dinar Köyü'nün yarısı, Kedağaz Köyü’nün neredeyse tamamı, Artemiş Köyü, Gödez Köyü, Geçmiş ve Ebu Ali köyleri, Alpkoz Köyü, Sarsısaray mezra'ası, Ahmed Danişmend Köyü, Aytak ve Cecehacı köyleri, Çomak mezra'ası, Tokat'taki Salur, Menciniki, Taylucahacı ve Odoba mezra'aları, Bayram mezra'asıyla birlikte ifkas Köyü, Difya Köyü, bir mezra'nın yarısını, Yıldız'da Karhın ve Gavras köyleri, Beduhtun tevâbiinden Saruyar Köyü'nün yarısı, Başviran Köyü, 24 baş öküz ve bütün alât ve esbabıyla beraber Fanik Köyü'nün 1/4'i, Salur mezrâ'sı, Komnat tevâbiinden Kızılöz Köyü, Tokat'taki Kızıltavuk mevzi'indeki iki bahçe, Soğukpınar mevz'i'indeki iki bağ, Koylancık bahçesi, Pazarbaşı Ebubekir'e mensub bahçe, Ağaçlıbağ yeri, Komnat'taki Dilkubağı bağı, Difya Köyü’ndeki beş adet bağ, Soğukpınar mevzî'inde tek taşlı değirmenin 3/4'ü, Henğame mevzî'inde Ekmekçi dükkânı, Cevherin Mahallesi'nde bir sofa, iki kışık oda, iki mutfak ve üzerinde bina bulunan bir ahırı müştemil menzil, 200 re's koyun ve yedi re's kısrak vakfedilmiştir.

36 Osmanlı Devleti'nin ilk döneminde adına rastlanan vezirlerden Sinanüddin Yusuf Fakih Paşa'nın baba adının Muslihüddin Musa, dedesinin isminin ise Mecidüddin İsa olduğu rivâyet edilir. Bkz. İ. Hakkı Uzunçarşılı, "Osmanlı Tarihine Ait Yeni Bir Vesikanın Ehemmiyeti ve İzahı ve Bu Münasebetle Osmanlılarda illk Vezirlere Dair Mütalaa", Osmanlı Hanedanı Üstüne Incelemeler, Seçme Makaleler, 2, İstanbul 2012, s. 25-32; i. Hami Danişmend, izahlı Osmanlı Tarihi Kronolojisi, C. V, İstanbul 1971, s. 8.

37 VGMA, D. 582, s. 255/178, 257/179; Danişmend, Kronoloji, s. 9.

38 VGMA, D. 582, s. 251/176, 253/177; Danişmend, Kronoloji, s. 9.

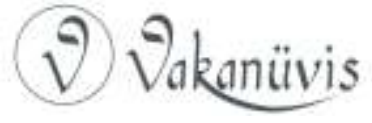


Timurtaş Paşa ahfadından Bayezid Paşa ${ }^{39 \prime}$ nın da BayezidiyyeKalenderiyye Tarikatı çevresinden olduklarını söylemek gerekir.

Bu belgelerin bize anlattıklarını şu başlıklar altında değerlendirmek mümkündür:

\section{Bedeviyye-Rıfâiyye ve Bistâmiyye-Kalenderiyye}

Seyyid Bedevî, İbn Arabî'nin dahi müridi olmak istediği çok önemli bir mutasavvıf olan Ebu Medyen Şuayb'ın anne tarafından torunudur. Fas'ta doğan Ahmed el-Bedevî, daha çocukluğundan itibaren "Zahid Ahmed" olarak tanınmış, ağabeyi vasıtasıyla Nişaburlu Abdülcelil'den tarikat hırkası giymiştir. Mekke'ye yerleştikten sonra, Rifâiyye şeyhlerinden Berrî tarafından seyr ü sülûka tâbi tutulan Bedevî, ağabeyi Şerif Hasan ile beraber 1236'da Irak'a giderek burada Abdülkadir-i Geylânî, Ahmed er-Rıfâî, Hallac-ı Mansûr, Ebu'l-Vefâ Bağdadî, Şeyh Musa ez-Zilî ve Adî b. Müsafir gibi zevâtın kabirlerini ziyaret etti. Aynı yıl Mısır'da Tanta'ya giden Bedevî, Mısır sultanlarından çok büyük saygı gördü. Mısır ulemâsı tarafından zaman zaman tepkiyle karşılanan ibadet tarzı ve yüzünü her daim bir peçe ile örtmesi ile dikkat çeken Ahmed el-Bedevî, bu özelliğinden dolayı "elmülessim/peçeli" ve "es-sütûhî" şeklinde tavsif edilmiştir ${ }^{40}$.

Bu çalışmada ele alınan vakfiyelerden hareketle Ahmed er-Rıfâi ve Abdülkadir-i Geylânî'ye üveysî olarak bağlı olduğu bilinen Ahmed elBedevî'nin Şeyh Osman-ı Velî ile olan sıhriyeti, Şeyh Osman'ın kim olabileceği hakkında da bir fikir verir. Bedevizâde Şemsüddin Ahmed'in Şeyh Osman-ı Rumî'nin oğlu Şeyh Alaüddin Ali el-Mücerred'den olan torunu Fatma Hatun ile evliliği ve Osman-ı Velî́nin "Muhiyüddin" unvanını taşıması üzerinden, Şeyh Osman'ın Abdülkadir-i Geylanî’nin oğlu Ebubekir Abdülaziz'in oğlu olan Şeyh Osman ile aynîliğine hükmedilebilir ${ }^{41}$. Ebu'l-Vefâ'nın müridlerinden Dede Garkın'a

\footnotetext{
${ }^{39}$ Vedat Turgut, "Vakıf Belgelerine Göre Osmanlı Devleti'nin Kuruluş Dönemi Aileleri II: Âl-i Timurtaş Paşa", Osmanlı Araştırmaları/The Journal of Ottoman Studies, S. 53 (2019), s. 63.

40 Baş, "Bedeviyye", Türkiye'de Tarikatlar, Tarih ve Kültür, s. 547-608; Mustafa Kara, "Ahmed el-Bedevî", TDViA, C. II, İstanbul 1989, s. 47-48.

${ }^{41}$ Abdulcabbar Kavak, "Şeyh Ebubekir Abdülaziz es-Sincarî (ö. 602/1205) ve Kâdiriyye Tarikatı'nın Kuzey Irak'taki Erken Dönem Faaliyetleri”, Akademik Bakış, S. 54 (MartNisan 2016), s. 147-160.
}

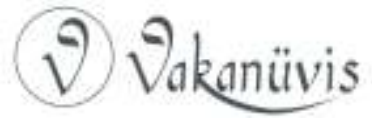


bağlanalar arasında adı zikredilen Şeyh Osman'ın da bu olması gerekir. Şeyh Osman-ı Velî’nin ahfadı ile Cemâlüddin Musa Zilî/Sâvî'nin ahfadı arasındaki ilişki ise, ikisinin arasının sonradan açıldığı ve Cemâlüddin'in "ehl-i sünnet"in itikadı dışına çıkarak Kalenderî olduğu yönündeki iddiaların reddini gerektirir. Öyle ki Şeyh Osman'ın oğlu Cemâlüddin Musa'ya intisab etmiş ve "el-mücerred" sıfatıyla vakıf kayıtlarında yer almıştır. Kaynaklarda Bayezidiyye müridi olarak adına rastlanan Hacı Tuğrul'un Ertuğrul Gazi olduğu düşüncesi, Osmanlı padişahlarının Bayezid Bistamî ve Veysel Karanîyye olan yakınlıklarını da açıklar. Osman-ı Velî ile olan sıhriyet, Ertuğrul Gazi'nin oğluna Osman adını koymasına vesile olduğu söylenebilir. Osman'ın "toy kuşunun, ejderhanın yavrusu" manasına geldiği ve Tuğrul'un da zümrüd-i Anka'ya benzer bir cennet-toy kuşu olduğu hatırlandığında, kadim dönemlerde isimlendirmenin ne kadar önemli ve incelikli bir ritüel olduğu daha iyi anlaşılacaktır.

Cemâlüddin Musa'nın, Emirce Sultan gibi Bayezid-i Bistamî'nin neslinden geldiği, o dönemde yaşayan bütün insanlara malûm olduğu ve bunun herkesçe kabul edildiği anlaşılır. Burada Kadîriyye, Rıfâiyye ve Bistâmiyye'nin uzantısı olan Kalenderiyye/Haydariyye ile elbette ki Ebu'l-Vefa Bağdadî'nin birbirlerini etkiledikleri açıktır. Bayezid-i Bistamî ile Ahmed er-Rıfâi'nin isimleri üzerinden dahi, bu hususu ortaya koymak mümkündür. Şöyle ki, "Bayezid" ismi "Ebu Yezid”in kısaltılmışı olup, "yezd'in babası" manasına gelir. Muaviye ve oğlu Yezid döneminde "ehl-i beyt"e karşı meydana gelen mel'un ve meşum olaydan dolayı, Muaviye ve Yezid isminin İslam dünyasında pek kullanılmadığı görülür. Bununla beraber, asıl adı Tayfur olan Bayezid-i Bistâmî'nin ve elbette onu takiben pek çok seyyid ve Osmanlı padişahlarının bu unvanı kullanması, ehl-i beyte düşmanlık olarak anlaşılmış gibidir. Halbuki burada "yezd" kelimesinin manası üzerinde tefekkür etmek icab eder. Bu kelimenin kökü "zeyd" olup, "arttırma/ziyadeleştirme" manasına gelir. Yani "Ebu Yezid", "arttıranların, ziyadeleştirenlerin babası" manasına gelir. Bu işi en iyi yapan pirlerden olduğuna buradan hükmetmek gerekir. Bu ismin Ahmed er-Rıfâî ile bağlantısı şüphesiz oldukça dikkat çekicidir. Kendisine atfedilen, peygamberin elini öpmesi kerâmeti dolayısıyla Abdülkadir-i Geylânî tarafından, sahabe ve müçtehidin dışında hiçbir velinin Ahmed er-Rıfâî́nin mertebesine çıkamayacağı müjdesi verilen

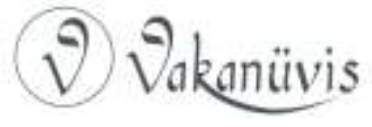


Ahmed er-Rıfâînnin bu nisbesinin, meşhur dedesi Ebu'l-Hasan'dan geldiği rivayet edilir. Ahmed Rıfâi'nin bu nisbesi, "esmaü'l-hüsna"dan "er-Rafi”" ismiyle alakalıdır. Allah'ın bu ismi de "şeref verip, yükselten, dilediğinin makam ve mertebesini arttıran" manasına gelir. Kelimenin Farsça manası da "Yezdan" ile ilintili olup, ibadet edilmeye en lâyık olan manasındadır. Yezdî ise ibadet edenler arasında mertebesi en yüksek olan şeklinde anlamlandırılabilir. Kelimenin Farsça'ya Sanksritçe'deki "Yect" kelimesinden geçtiği sanılır. Buradaki " $z$ " harfi ile "c" harfi arasında geçişin bir benzeri, "Zengi" ile "Cengi" kelimelerinde de görmek mümkündür ki bu konu, "Renklerin Efendileri" adlı çalışmada ele alındığından burada teferruata girilmeyecektir. Ortaya konulan bu argümanların sonucu, kısım başlığında ortaya konulmuştur.

“Üveysî" yoldan Rıfâî şeyhi olduğu bilinen Mahmud Hayranî’nin müridi olan Sarı Saltuk'un müridleri arasında "Haydarı̂" nisbesini taşıyan birinin olması, artık daha iyi anlaşılabilmektedir. Sarı Saltuk'un en ünlü müridi olup, Moğol-ilhanlı idarecileri üzerinde derin bir tesir bırakmış olan Barak Baba'nın da Rıfâî-Bayezidî-Kalenderî anlayışı temsil eden bir derviş olduğunu da burada anmak gerekir. Bu meşrepte bulunan sufîlerde görülen ilgi çekici hallerin, şer'iate mugayir heterodoks düşünceye sahip olduklarına yönelik teze sened teşkil edemeyecekleri de ortadadır ${ }^{42}$.

Günümüzde dahi varlığını sürdüren ve kendi içine kapalı olan Yezidiyye konusundaki araştırmalar da bu bağlamda ele alınmalıdır. Muaviye'nin oğlu Yezid ve onun soyundan geldiğine inanılan Adîyy bin Müsafir'e bağlanan Yezidîlik, aslında Bayezîd-i Bistamî ve Ahmed elBedevî'ye dayandırılan Bayezidiyye ve Bedeviyye'nin bozulmuş şekli olmalıdır. Ahmed el-Bedevî́nin damda geçirdiği riyazet sırasında güneşe bakmaktan gözlerinin kızarması, Yezidiyye'de güneş önünde

\footnotetext{
42 Konu hakkında bkz. Vedat Turgut, "Sarı Saltuk, Ona Ait Türbeler ve Ejderha Kültü’ne Dair", Rumeli'de Osmanlı Vakıfları Üzerine Araştırmalar: Bulgaristan, (Ed. A. Kala vd.), İstanbul: Vakar Yayınları, 2020, s. 145-167; Mustafa Koç, "Eski Anadolu Türkçesi Karışık Dilli Metinlerinden Barak Baba Manzumesi", Hacettepe Üniversitesi Türkiyat Araştırmaları Dergisi, 28 (2018), s. 281-300; Muhammed b. Ali b. Es-Serrac, Tuffahü'lErvâh ve Miftahü'l-irbah, (Haz. N. Gürkan-M. N. Bardakçı-M. S. Sarıkaya), İstanbul: Kitap Yayınevi, 2015, s. 64-69, 319-326; Ahmet Yaşar Ocak, Sarı Saltık: Popüler İslam'ın Balkanlardaki Destanî Öncüsü (13. Yüzyıl), İstanbul: Kitap Yayınevi, 2016.
}

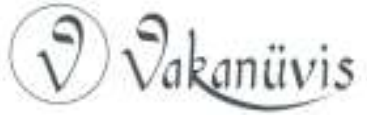


yapılan ibadet ile benzeşir. Fakat Bedeviyye'nin esasları gözönüne alındığında Ahmed el-Bedevî́nin Yezidî ya da Uzak-Doğu dinleriyle bağlantılı olduğunu düşünmek mümkün değildir. Tam tersine, Yezidîlerin bu ibadet biçimini kendi düşünüş biçimlerine uydurdukları anlaşılmaktadır. Bedevî̀nin güneşe bakarak riyazete çekilmesi, İslamî ibadetlerde güneşin itibara alınmasıyla ilgili olabilirse de bunun bir tapınma olmadığı açıktır. Dünyanın kendi etrafında dönerken diğer yandan güneşi de tavaf etmesi sonucunda aldığı konumlar, İslamî ibadetlerin vakitlerinin ölçülmesinde belirleyicidir. Bunun yanısıra güneş, dünyadaki hayatın devamlılığı için de vazgeçilmez bir yere sahiptir. Zaman içinde güneşe gösterilen bu saygının abartılarak, onun tanrı yerine konulduğu müşahede edilir. Aynı şey kamer/ay için de geçerlidir. Bunu, insanoğlunun hayatında gereğinden fazla değer atfettiği para, unvan, makam-mevkî, sevgili gibi pek çok şeye teşmil etmek mümkündür. Adîyy bin Müsafir'in Vefâiyye, Kadiriyye, Sühreverdiyye ve Rıfâiyye ile çok yakın ilişki içinde olan sünni bir mutasavvif olduğu da belirtmek gerekir. Yezidîlerde Allah'ın "Hudâ" adına ayrı bir önem verilmesi de Bayezid-i Bistâmi'nin Veysel Karanî̀ye bağlılığına izafeten "Üveysiyye" olarak adlandırılan tasavvufî görüşle yakınlığını gösterir. Bilindiği üzere, Bayezidiyye yani üveysîlik ile tarihsel bağları artık aşikâr olan ilk Osmanlılar; Osman, Orhan, Murad ve Bayezid, "Hüdâvendigâr" unvanını kullanmışlardır. Burada "Hüdâ" isminin Esmaü'l-Hüsna'daki karşılığının "Ahad" olabileceği üzerinde düşünülmesi gerektiği özellikle belirtilmelidir. Bedeviyye'nin Mısır'daki etkisinin, Bektaşiyye'nin Anadolu ve Rumeli'deki etkisine benzetilmesi de bu bağlamda manidardır. Aziz Mahmud Hüdayî'nin Vakıat adlı eserinde $\mathrm{Hacl}$ Bektaş Velî ile Ahmed el-Bedevî arasındaki kerametlerden bahsetttiğine de burada değinilmelidir ${ }^{43}$.

Bistamiyye-Kalenderiyye ve Mevleviyye

\footnotetext{
43 Mustafa Kara, "Bedeviyye", TDVIA, C. V, (İstanbul 1992), s. 318-319; Kara, "Ahmed el-Bedevî", s. 47-48; Ahmet Taşğın, "Yezidiyye", TDViA, C. XLIII, (i̇stanbul 2013), s. 525527; Süleyman Uludağ, "Adî b. Müsafîr", TDViA, C. I, (İstanbul 1988), s. 381; Turgut, Osmanlı Devleti'nin Kuruluş Coğrafyasında Vakıflar ve Şehirleşme, Bilecik 2015, s. 61, 82-91, 117; Osman Gazi'nin Akbaş Derviş için kurduğu vakıf kaydına "Hüdâvendigâr" unvanını kullandığı görülür. Bkz. TADB. TTD. EV. 585, v. 284a.
}

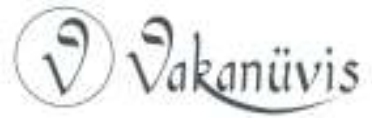


Kalender Baba'nın asıl adı Ebu Bekir Niksarî olup, türbesi Konya'dadır. Cemâlüddin Zilî’nin yakın arkadaşı ve müridi olan Kalender Baba ve ona bağlı müridlerin Mevlana Celalüddin Rûmî ile yakın ilişkilerinin olduğu tarihi kayıtlarla sabittir. Celalüddin Rûmî'nin cenaze törenine katılan kalenderîlerin, "Allah'tan gelen, Allah'a rücu" eder manasında "Ya Hayy, Ya Huyy" zikrine devam ettikleri de müşahidlerin anlatılarına yansımıştır ${ }^{44}$. Halk arasında Başıkesik Türbesi'nin Şems-i Tebrizîyye ait olduğu söylense de bu isimle pek çok türbenin var olduğu da bilinir. Cemâlüddin Musa'ya Şam'da iken mürid olanlar arasında yer alan Şemsüddin Belhî, muhtemelen Şemsüddin Tebrizî ile aynı kişiydi. Mevlana'yı oldukça etkileyen Şems'in, Mevlana'nın babasının şeyhi Necmüddin Kübrâ'nın müridi Baba Kemal'den irşad gördüğü bilgisi, bu gezgin (perende) şeyhin Mevlana ile temelde aynı pınardan beslendiklerini düşündürür. Şems'in Mevlana'ya "peygamber mi üstündür, yoksa Bayezid-i Bistamî mi?" şeklindeki sorusu da Bayezidiyye/Kalenderiyye'nin piri Cemâlüddin Musa'ya bağlananlar arasında yer alan Şemsüddin Belhî'nin, Şems-i Tebrizî ile aynı kişi olduğuna bir başka delil sayılabilir. Şems'in de kara keçe giyip, kendini halktan gizlemesi, Ahmed el-Bedevî'ye benzetilebilir ${ }^{45}$. Son İsmailî daîlerinden Celalüddin Nev-müslüman'ın Şems Tebrizî́nin babası ya da dedesi olduğuna yönelik rivâyetler, Tokat'ta bulunan "Yeni-Müslüman" adlı idarî birimle bir arada düşünüldüğünde önem kazanır. Bu, O'nun Tokat havalisinde zaviye kuran Cemâlüddin Musa'ya tâbi olduğu yönündeki fikri destekler mahiyettedir ${ }^{46}$.

\section{Bistamiyye/Kalenderiyye, Bektaşiyye, Vefâiyye, Sühreverdiyye ve Kadîriyye}

Cemâlüddin Musa'nın en meşhur müridleri arasında Karaca Ahmed ve babası Rumtaş Paşa yer alır. Enisî tarafından kaleme alınan Karaca

\footnotetext{
44 Ocak, Kalenderiler..., s. 59, 196-198; Ahmed Eflakî, Menâkıbü'l-Kudsiyye, Ariflerin Menkıbeleri, ìstanbul 2012, s. 453-454.

${ }^{45}$ Semih Ceyhan, "Şems-i Tebrîzî", TDVIA, C. XXXVIII, İstanbul 2010, s. 511-516; YazıcI, "Cemâlüddin Sâvî", s. 313-314.

${ }^{46}$ Ocak, Kalenderîler, s. 71; TADB. TTD. EV. 583, v. 29b, 33b-34a, 47b.
}

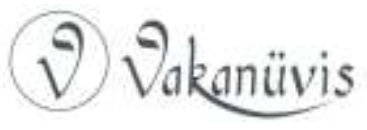


Ahmed Sultan Menâkıbnâmesi ${ }^{47}$, Karaca Ahmed'in çocuklarının isimlerini tahrir defterleriyle uyumlu bir şekilde verir. Buna göre, "Şeyh Paşa ve kardeşi Şeyh Muhammed Paşa Şeyh Hacı ihsan Paşa'nın oğullarıdır. Yusuf Paşa ve Rum Paşa oğullarıdır. Hacı Musa Paşa oğlu Molla Veled oğludur. Bunlar devletin ışığı Molla Yusuf Paşa oğlu Veled Paşa oğludur. Şeyh Kasım Paşa hazretleri, Abdi Paşa oğludur. Bunlar Rum Paşa oğullarıdır. Bunlar Hacı Musa Paşa ve Yusuf Paşa oğullarıdır". Burada zikredilen Molla Veled'in, yukarıda vakfiyyeler kısmında adına rastlanan kişiyi akla getirir. Hacı Bektaş Velî́nin bağlıları arasında, Cemâlüddin Musa'nın Bayezid adındaki oğlunun da olduğu buradan anlaşııır. Karaca Ahmed evlâdından Kasım Paşa'nın, Beypazarı'ndaki Dil Dağı'nda vahşi hayvanlarla yedi yıl yaşadığı belirtilir. Karaca Ahmed'e "Karaca" lakabının şeyhi Musa Zilî tarafından verildiği, bunun da karaca çobanlığı yapmasıyla ilgili olduğu rivâyet edilmektedir. Karaca Ahmed adına Pamukova, Polatlı, Aydın, BursaYenişehir, Manisa-Akhisar, Uşak, İznik, Kütahya ve Malkara'da evladı tarafından pek çok zaviyenin kurulduğu görülür. Onun asıl türbesi, Pamukova'da olup, diğerlerinin evladına ait olduğu anlaşılır ${ }^{48}$.

Karaca Ahmed evlâdından Rum Paşa Seydi'nin adına Malkara'da kurulan vakıf dolayısıyla rastlanır. Onunla aynı adı taşıyan dedesi adına, Anadolu'nun pek çok yerinde zaviyeler kurulduğu görülür. Karaca Ahmed Seydi'nin Gülbenk Paşa adındaki diğer oğlunun da Germiyan topraklarında bir zaviye bina ettirdiği tespit edilmiştir ${ }^{49}$. Sözlü

\footnotetext{
47 Bkz. Karaca Ahmed Sultan Menâkıbnâmesi, (Haz. D. Gümüşoğlu), İstanbul 2013, s. 33, 141-145.

48 Necdet Tosun, "Karaca Ahmed Hakkında Yeni Bir Kaynak ve Meçhul Kalmış Bilgiler", Uluslararası Üsküdar Sempozyumu V, (1-5 Kasım 2007), C. II, İstanbul 2008, s. 323-328; Hüseyin Özcan-C. Sezen Gönenç, "Yazılı ve Sözlü ortamlardaki Karaca Ahmet Sultan Menkabelerinin Karşılaştırılması", Turkish Studies, C. 10/4, (Kış 2015), s. 717-746; Karaca Ahmed Sultan Menâkıbnâmesi, s. 33, 131, 141-145.

49 Barkan, "Kolonizatör Türk Dervişleri...", s. 343; Turgut, "Orhan Gazi Dönemi ve Vakıfları", Uluslararası Orhan Gazi ve Kocaeli Tarihi-Kültürü Sempozyumu Bildirileri-V, C. I, (Kocaeli: Belediye Yayınları, 2019), s. 444-445; Ergin Türkel, 16. Yüzyılda Kütahya Sancağı Vakıfları (Emet, Denizli, Uşak, Burdur), Bilecik Şeyh Edebali Üniversitesi, Sosyal Bilimler Enstitüsü, 2017, s. 117; TADB. TTD. EV. 560, v. 187a.
}

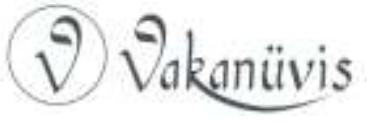


kaynaklar, Karaca Ahmed'in oğulları arasında Hızır Abdal, Gani Abdal, Kamber Abdal ve Eşref Abdal'ın isimlerini de zikrederler ${ }^{50}$.

Karaca Ahmed adına kaleme alınan menâkıbta, Sultan'ın babasının adı Melik Şihabüddin Abdullah bin Kara Arslan şeklinde verilmiş ve ailenin kökeninin Mardin'de olduğu ayrıca belirtilmiştir ${ }^{51}$. Buradan, Karaca Ahmed'in Artukoğulları sıhriyeti de netlik kazanır. Menâkıbnâmeye göre, Karaca Ahmed'in annesi Safiye Hatun, Musa Zilî’nin kızından doğmuştur. Bu durumda birazdan ele alınacağı üzere, Emir Celalüddin Karatay'ın kardeşi Kemalüddin Rumtaş'ın (Rum Paşa), Cemâlüddin Musa'nın kızı ya da torunuyla evlendiği ve ona mürid olduğu söylenebilir. Anadolu erenlerinin "gözcüsü" olan Karaca Ahmed de "tabiblerin piri" olarak kabul edilir. Daha da önemlisi, Karaca Ahmed evlâdından en ünlüsünün adı Rum Paşa, Rum Paşa'nın oğlu ise, Abdullah'ın kısaltılmış hali olan Abdi Paşa'dır ${ }^{52}$. Ahi Evren'in tasarruf ettiği zaviyelerden birinin, vezir Zeynüddin Kara Arslan tarafından bina ettirildiği bilinir.

Karaca Ahmed adına Malkara'da kurulan zaviyenin hemen yanında Gazi Murad Hüdâvendigâr zamanında "Ahi Musa Zaviyesi" adına kayıtlı bir zaviye de dikkati çeker. H. 767'de Receb ayının gurresinde düzenlendiği anlaşılan vakfiyeye ulaşılamasa da tahrir defterinden vakıf hakkında ayrıntılı bilgi edinmek mümkündür. Vakfın tevliyeti önce erkek, sonra kız evladının nesline şart edilmiş, Ahi Musa'nın ahilik beratı verdiği akraba ve damatlarının dahi kayıt altına alınması vakfiyede ayrıca belirtilmiştir. Ahi Musa'dan sonra zaviyeyi, Ahi Mustafa ve Ahi Tayfur'un tasarruf ettiklerine dair kayıt, konumuz açısından çok önemlidir. Bilindiği üzere Bayezid-i Bistamî'nin gerçek adı Tayfur'dur. Bu, Karaca Ahmed Zaviyesi'nin yanında bulunan bu zaviyenin Cemâlüddin Zilínnin torunu olan hem-nâmı tarafından kurulduğuna en önemli delildir. Zaviyeyi, Ahi Tayfur'dan sonra oğlu Ahi Mahmud, II. Bayezid zamanında tasarruf ederken, Ahi Musa'nın diğer

50 Özcan-Gönenç, "Yazılı ve Sözlü ortamlardaki Karaca Ahmet Sultan Menkabelerinin Karşılaştırılması", s. 717-746; Karaca Ahmed Sultan Menâkıbnâmesi, s. 33vd.

${ }^{51}$ Hüseyin Özcan-C. Sezen Gönenç, "Yazılı ve Sözlü ortamlardaki Karaca Ahmet Sultan Menkabelerinin Karşılaştırılması", s. 717-746; Karaca Ahmed Sultan Menâkıbnâmesi, s. 33.

52 Turgut, "Orhan Gazi Dönemi ve Vakıfları", Uluslararası Orhan Gazi ve Kocaeli TarihiKültürü Sempozyumu Bildirileri-V, C. I, (Kocaeli: Belediye Yayınları, 2019), s. 444-445.

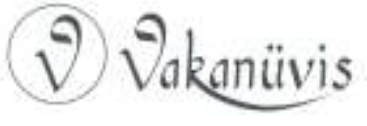


oğlu Ahi Mustafa'nın kızının torunu Mehdi(ye) Hatun'a tevzî̀ etmiş ve tevzî'nâme Mehdi Hatun'un eşi Ahi İshak'a verilmiştir. Bundan sonra oldukça yaşlı olduğu anlaşılan Ahi Mahmud yerine Ahi İshak, zaviyenin başına geçmiştir. Zaviye için Malkara dahilindeki Ahi Musa Çiftliği vakfedilmiş olup, büyük bir kısmı çiftlikte yetişen bağlardan sağlanan önemli bir geliri vardır. Yine şehir içinde Ahi Musa tarafından bina ettirilen bir başhane de vakfın gelirleri arasında yer alır ${ }^{53}$.

Dedigi Sultan menakıbına göre Karaca Ahmed, Emir Sultan'ın kardeşinin oğludur ${ }^{54}$. Burada Emir Sultan olarak belirtilen kişi Celalüddin Karatay'dır. Şöyle ki evkâf kayıtları, "Dayı Sultan" şeklinde de okunabilecek olan fakat esasen "Tayî/Tay Sultan" şeklinde okunması gereken çok önemli bir şahsiyete işaret eder. Tay, soy manasına gelir ve tayî de soylu demektir. Bu kayıtlara göre; Aydın Sancağı'a bağlı olan Tire'de Aydınoğlu Umur Bey ve İsa Bey, Güllüce Köyü'nün gelirini Tayî Seydi evlâdı için vakfetmiştir ${ }^{55}$. Tayî Seydi adına Kastamonu'da Candaroğulları ve Osmanlılar döneminde yapılan vakıflar da bulunur. Kastamonu'nun merkezinde Tayî Sultan adına bina ettirilen zaviyenin, Tayî Sultan evlâdından Seydi Ahmed, Seydi Mehmed, Seydi Mahmud ve Seydi Sinan adlarındaki şeyhler tarafından tasarruf edildiği anlaşılır. Vakfın son mutasarrıfı Seyyid Mahmud Fakih'tir ${ }^{56}$. Tokat'ın merkezinde de "Ahi Kâmil" adıyla meşhûr olduğu belirtilen Ahi Tayî adına bir zaviye bina edildiği görülür. Zaviyeyi Şeyh Ali ve Mustafa Çelebi adlarındaki zevâtın tasarruf ettiği belirtilmiştir ${ }^{57}$. Anadolu'nun batısında çok geniş bir coğrafyada etki bırakmış olan bu şahsiyetin kim olabileceği üzerinde durmak bu safhada oldukça önemlidir.

\footnotetext{
53 BOA. TD. 75, s. 537-539. Belgenin çeviri metni için bkz. 75 Numaralı Gelibolu Livâsı Mufassal Tahrir Defteri (925/1519), I, (Haz. A. Sivridağ vd.), Devlet Arşivleri Yayınları, Ankara 2009, s. 197-198; Ö. L. Barkan, "Kolonizatör Türk Dervişleri", s. 343.

54 Ahmet Taşğın, Dediği Sultan ve Menâkıbı (Konya ve Çevresinde Ahmet Yesevî Halifelerinin Izleri), Konya: Çizgi Kitapevi, 2013, s. 97.

55 M. Akif Erdoğru, Kanuni Sultan Süleyman Devri Aydın ili Evkâf Defteri, (İzmir: Ege Üniversitesi Yayınları, 2016), s. 135-137, 516-517; TADB. TTD. EV. 571, v. 55a-56a.

56 TADB. TTD. EV. 554, v. 25a-b, 119b; TADB. TTD. EV. 555, v. 169b-170a, 188a-189a, 228a, 233a.

57 TADB. TTD. EV. 583, v. 31b.
}

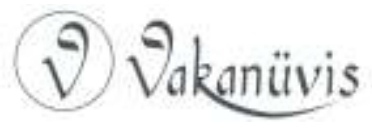


Gökbilgin, Tokat'taki vakıfların kurucusu olduğu için Zeynüddin Tüli Seydi oğlu Tacüddin İbrahim Bey'in ${ }^{58}$ Tay Sultan olduğunu belirtmişse de esasen Tayî Seydi'nin Celalüddin Karatay olduğu, diğer tarihî verilerle beraber düşünüldüğünde kesindir. Celalüddin Karatay, 12121252 yılları arasında Selçukluların hizmetinde bulunmuş, Alaüddin Keykûbad döneminde taşt-dârlık vazifesinde bulunarak Sultan'ın sırdaşları arasında yer almış bir devlet adamıdır ${ }^{59}$. Hamidoğulları'nın atası olan Necmüddin Ebu'I-Kasım ile beraber, Sühreverdî'nin Konya'yı ziyareti sırasında şeyhe intisab eden Karatay'ın babasının ismi, tescil ettirdiği vakfiyesinde Abdullah olarak kayıtlıdır. Selçuklu tarihlerinin kendisini "Rumî" olarak kaydetmiş olması, Sultan'ın hizmetlilerinden olduğunun belirtilmesi ve baba adının muhtedîlerin baba isimleri gibi kaydedilmiş olması sebebiyle onun Müslüman olmayan bir aileden geldiği fikri kabul edilmiş görünür ${ }^{60}$. Vakfiyede Karatay'ın babası Abdullah'ın "tâbiblerin emiri" sıfatıyla vasıflandırılması oldukça önemlidir. Çünkü Karatay'ın bina ettirdiği büyük kervansarayda da bir bimarhanenin bulunduğuna dair işaretler vardır. Onun "taşt-dâr"lık görevinde olması tabipliği ile yakından ilgilidir. Karaca Ahmed ve babası Rumtaş Paşa da tabipler arasında zikredilir ${ }^{61}$. Vakfiyenin tevliyet şartları belirtilirken, Karatay'ın kardeşleri hakkında da bilgi sahibi olunabilmektedir. Buna göre, Kemalüddin Rumtaş ve Seyfüddin

\footnotetext{
58 Tarihî literatüre Eratna Bey şeklinde yerleşmiş olan Erdana Bey'in Amasya ve Tokat'ı Zeynüddin Tüli Bey'in tasarrufuna bıraktığı ve Tüli Seydi'nin oğlu Tacüddin İbrahim Bey'in de 1350'li yıllarda Tay Seydi adına bir zaviye bina ettirdiği bilinir. Bkz. M. T. Gökbilgin, "Tokat", İslam Ansiklopedisi, 1979, XII/1, s. 403; Kemal Göde, "XIV. Yüzyılda Tokat/Eratnalılar Hâkimiyetinde Tokat", Türk Tarihinde ve Kültüründe Tokat Sempozyumu, (2-6 Temmuz 1986), (Ankara: Gelişim Matbaası, 1987), s. 20; Kadir Özköse, "Tokat'ta Tasavvuf Kültürü", Gazi Osmanpaşa Üniversitesi, Tokat Tarihi ve Kültürü Sempozyumu, (25-26 Eylül 2014), Bildiriler, C. III (2015), s. 82/79-102.

59 Osman Turan, "Selçuklu Devri Vakfiyeleri-III, Celâleddin Karatay, Vakıfları ve Vakfiyeleri", Belleten, C. XII, S. 45, (Ankara 1948), s. 17-170; İbn Bibî, El-Evâmirü'lÂlaiyye, s. 253-254.

60 Turan, "Celâlüddin Karatay, Vakıfları ve Vakfiyeleri", s. 17-21; VGMA, D. 577, s. 28/21; Turgut, "Hamidoğulları ve Tekeoğulları'nın Menşei ve Vakıflarına Dair", Journal of Turkish Studies/Türklük Bilgisi Araştırmaları, (Ed. Cemal Kafadar-Gönül A. Tekin), V. 46, (December 2016), s. 403-432.

61 Turan, "Celâlüddin Karatay, Vakıfları ve Vakfiyeleri", 57-58, 114; VGMA, D. 577, s. $28 / 21$.
}

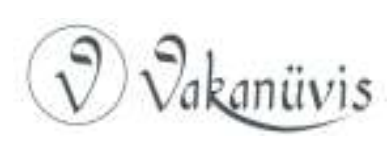


Karasungur adlarında iki kardeşi bulunmaktadır62. Celalüddin Karatay'ın zaviyesine dair vakıf kaydında "Karatay Sultan" şeklinde kaydedilmiş olması, Anadolu'nun pek çok yerinde "Tay(î) Sultan" adına kurulan vakıfların, onun adına kurulduğunu gösterdiği gibi, onun seyyidlerden olduğuna da işaret eder. Bu durumda onun Hıristiyan bir aileden geldiği yönündeki genel kabulden vazgeçilmesi gerekir.

Dolayısıyla Karaca Ahmed Sultan ile Karatay Sultan'ın Mardin Artukluları ile bir sıhrîyyetinin olduğu, seyyidlerden oldukları ve ailenin tıp ilimlerinde uzmanlaştıklarını söylemek mümkündür. Selçuklu Devleti'nin 1249-1252 yılları arasında "triumvirlik"63 olarak adlandırılabilecek olan dönemin mimarlarından olan Karatay'ın, Sühreverdiyye'nin bir şubesi olarak değerlendirilebilecek olan Evhadiyye'ye bağlı bir şeyh olan Ahi Evren'i hapisten kurtarması, bu durumda daha anlamlı bir hal alır. Şihabüddin Sühreverdî’den sonra "şeyhü'ş-şüyûh" olan ve Sühreverdiyye'nin bir uzantısı olarak görülen Evhadiyye Tarikatı'nın kurucusu Evhadüddin Hamid-i Kirmanî'den sonra fütüvvet erbabının reisi olan Ahi Evren'in Karatay'ın babası tarafından kurulan zaviyeyi tasarruf etmesi de bu sıhriyetle alakalıdır. Ahi Evren'in Abdülkadir-i Geylânî'nin torunlarından olduğuna işaret eden tahrir kayıtları da bu düşünceyi destekler ${ }^{64}$.

Sultan Murad'ın vakıflar tahsis ettiği kalenderhaneler Malkara'daki örneklerinden ibaret değildir. Osmanlı hanedanının "Murad" ve "Bayezid" isimlerini sıkça kullanmaları, Üveysî-Bayezidî anlayışa sahip bir aileden geldiklerini gösterir. Murad, Veysel Karanî'nin bağlı bulunduğu aşiretin adı olup, oğluna "Şah-ı Bistâmı̂”nin adını verdiğine Osmanlı tarihleri de değinir. Bayezid’in eşlerinden Aydınoğlu İsa Bey'in kızı Hafsa Hatun'un vakıflarının tevliyetini Bistâmî müridlerinden Abdülgaffar Çelebi'ye şart etmesi de çok önemlidir65. Murad

\footnotetext{
62 Turan, "Celâlüddin Karatay, Vakıfları ve Vakfiyeleri", 18-20, 34, 47-52, 66, 72, 80, 89, 111, 115-119, 140-143; VGMA, D. 577, s. 28/21.

${ }^{63}$ Bu tabir, Roma İmparatorluğu'nun Jul Ceasar, Pompei ve Crassus arasında í. Ö. 63 yılında ve Octavianus, Marcus Anthonius ve Lepidus arasında i. Ö. 43 yıllarında yaşanan idari sistemi anlatmak için kullanılır.

${ }^{64}$ Bkz. Turgut, "Renklerin Efendisi", Uluslararası Milli Mücadelede Servetiye Cephesi ve Kocaeli Tarihi-Kültürü Sempozyumu Bildirileri-VI, C. I, (Kocaeli: Belediye Yayınları, 2020), s. 101-118.

65 Turgut, “Âl-i Timurtaş Paşa...”, s. 63.
}

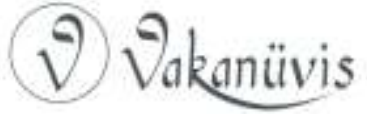


Hüdâvendigâr'ın vakıf yaptığı Bayezidiyye/Kalenderiyye şeyhleri, sadece Malkara'daki Karaca Ahmed ve Ahi Musa'dan ibaret değildir. O, Bursa'da Şemsüddin Ahmed b. Pir Gaybü'l-Kalenderî adına bir kalenderhâne inşa ettirmiştir ${ }^{66}$. Onun Karamanoğlu Alaüddin Ali Bey ile evlendirdiği kızı da Konya'da pek çok kalenderhane için vakıflar tahsis etmiştir. Örneğin Hacı Mübarek Şah'ın halifesi Şeyh Muhammed Haydarî Zaviyesi bunlardan biridir. Onun Larende'de kurduğu haydarîhanenin tasarrufunun ise Mevlevîlerde olduğu görülür. Şehirde ayrıca bir kalenderhane daha vardı ${ }^{67}$. Anadolu'nun pek çok yerinde kalenderhane ve haydarîhane gibi isimler altında kurulan zaviyelere rastlanır. Tokat, Konya, Larende, Beyşehir, Kırşehri, Kayseri, Mardin, Ankara, Bayburt, Kastamonu, Aksaray, Milas, Birgi ve Ayasuluğ gibi yerler bunlardan sadece öne çıkanlardır ${ }^{68}$. Pir Ebi Sultan ve oğlu Yalıncak Baba ile torunları Gökbaşlu Seydi İsmail'in de haydârîkalenderî kişiler olarak Anadolu'nun pek çok yerinde zaviyeleri vardı ${ }^{69}$.

Karaca Ahmed'in, Bistamiyye müridi Hacı Tuğrul ile var olan sıhriyyeti, Bistamiyye neslinden gelen mürşidi Hacı Musa Zilî ile ilgilidir. Hacı Bektaş Velî’yi karşılayan bir eren olarak karşımıza çıkan $\mathrm{Hacı}$ Tuğrul'un $^{70}$ kimliği meçhul olmakla beraber, dedesinin adıyla müsemma olan Kırşehri'nde Alaüddin Keykubad döneminde valilik yapan Seyfüddin Tuğrul'u işaret ettiği ve bu kişinin de Ertuğrul Gazi ile aynı kişi olduğu üzerinde artık ciddiyetle düşünülmelidir. Seyfüddin Tuğrul ile Ertuğrul Gazi'nin aynı kişi olduğu, Ahi Evren tarafından "Kır"şehri valisine ithaf edilen "Menahic-i Seyfî" adlı eserin başına konulan kırmızı bir mürekkeb ile yazılmış bir kayıtta değinilir ${ }^{71}$. Ertuğrul Gazi'nin atası olarak tahrir defterlerinde "Nu'man oğlu Kır/Kayır Han" mukayyed olup, buradaki Nu'man'ın Şeyh Nu'man olduğu ve gerçek adının Sultan İsmail olduğu bilindiğine göre, yukarıda ele alınan Emirce

\footnotetext{
66 Ö. L. Barkan-E. Meriçli, Hüdâvendigar Livâsı Tahrir Defterleri, I, Ankara 1988, s. 38.

67 Sadullah Gülten, "Tahrir Defterlerine Göre Anadolu'da Kalenderîler ve Haydarîler", Tarih Araştırmaları Dergisi, C. 31, S. 52, (2012), s. 35-53; TADB. TTD. EV. 565, v. 73a74a; TADB. TTD. EV. 584, v. 33b. Ayrıca bkz. TADB. TTD. EV. 564, v. 33a.

68 Sadullah Gülten, "Tahrir Defterlerine Göre Anadolu'da Kalenderîler ve Haydarîler", s. 35-53.

${ }^{69}$ Konu hakkında ayrıca bir makale hazırlanmaktadır.

70 Ahmet Taşğın-Bünyamin Solmaz, "Hacı Bektaş ve Hacı Toğrul Karşılaşması: Güvercin ve Doğan Donuna Bürünme", Turkish Studies, V. 7/1, (Kış 2012), s. 105-129.

${ }^{71}$ Turgut, "Renklerin Efendisi", s. 101-118.
}

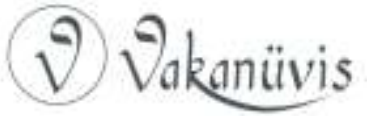


Sultan ile aynı kişi olduğu ya da aynı aileden geldiği fikri burada yeniden hatırlanmalıdır. Bu da Bistâmiyye ile Vefâiyye'nin, Şeyh Nu'man'da birleştiğini gösterir.

\section{Üveysiyye/Bistamiyye/Kalenderiyye, Yeseviyye ve Nakşibendiyye}

Burada öncelikle Kutbüddin Haydar hakkında yukarıda özetlenen bilgileri anımsayarak, Kutbüddin Haydar ile Cemâlüddin Musa arasında hiçbir yakınlığın olmadığı yönündeki ifadeleri sorgulamak elzem görünür. Kutbüddin Haydar'ın babası olduğu düşünülen Şahver'in ${ }^{72}$, esasında Bistam kentine sadece $6 \mathrm{~km}$ uzaklıkta bulunan "Şahrud" isimli yerleşim birimini işaret edebileceğinin altı çizilmelidir. Cemâlüddin Musa'nın Save, Kutbüddin Haydar'ın ise Zave adı verilen yerlerde dünyaya geldikleri bilinir. Bunlardan Save, İran'ın merkez eyaletlerinden birinde yer alır. Zave ise, Horasan bölgesindeki Meşhed sınırları içinde bulunur. Cemâlüddin Musa ve ahfadına dair vakfiyede, şeyhin Horasan'da doğduğu açıkça belirtildiğine göre, Cemâlüddin Musa'nın da Zâveî şeklinde anılması icab eder. Bistamiyye neslinden oldukları tarihi rivâyetlerde yer alan ve Haydarî-Kalenderîliği teşkilatlandırdığı belirtilen bu iki şahsın aslında aynı kişiler ya da babaoğul oldukları düşüncesini önermek, yukarıda anılan gerekçelerin tamamı üzerinden düşünüldüğünde fazla cesur bulunmamalıdır. Bu kişilerin vefat tarihleri de birbirlerine çok yakın verilmiş olup, doğum tarihi belli olmamakla beraber, uzun bir ömür sürdükleri söylemi de bu bağlamda önemlidir. Cemâlüddin Zilî́nin "Kutbüddin" sıfatını da kullandığı, vakfiyelerde evsafı üzerinden anlaşılır. Hiç olmazsa, birbirleriyle kan bağının bulunduğu kabul etmek gerekir. Haydar isminin, vücudun çeşitli yerlerine taktıkları takılardan dolayı verildiği üzerinde de düşünülmelidir. Bu, Allah'a kulluk anlayışının bir dışa vurumu olarak görülür. Aynı zamanda "Arslan" "cesur, yiğit" anlamlarında da kullanılan Haydar ismi, Moğollara karşı yapılan "gaza" ile de ilgilidir. Kutbü'l-Ârifin Cemâlüddin Musa/Kutbüddin Haydar'ın Zave'den Şahrud'a geldiği, burada dedeleri Bayezi-i Bistâmî'ye üveysî yolla intisab ederek, Kalenderî/Haydarî olarak tanımlanacak olan tarikatı, aslında Bistâmiyye olarak isimlendirdiklerini söylemek mümkündür. Yani, Bistamiyye Tarikatı'na bağı olan dervişlerin "kalender-meşreb" bir ruh haline sahip olduklarını belirtmek gerekir.

72 YazıcI, “Haydar, Kutbüddin”, s. 24-25.

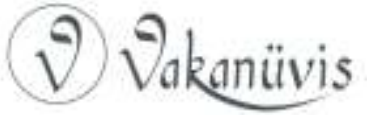


Bistam kentine yakın bir yerde bulunan Harakan'da dünyaya gelen Ebu'l-Hasan Harakanî'nin de üveysî yolla Bayezid-i Bistamî’ye mürid olduğu, hatta Mevlana'nın ifade ettiği üzere Şah-ı Bistamî'nin Harakan'da kendisinden sonra dünyaya gelecek olan Ebu'l-Hasan'ı hal-i hayatında iken müjdelediği de bilinir. Anadolu'nun fethi sürecinde çok önemli vazifeler üstlendiği anlaşılan Harakanî gibi Nakşibendiyye silsilesi içinde çok önemli bir yeri olan Abdülhalik Gücdüvanî de Kutbüddin Haydar gibi Ahmed Yesevî'nin müridleri arasında zikrediliir ${ }^{73}$. Yusuf Hemadanî'nin müridi olan Ahmed Yesevî'nin şahsında "Hacegân" olarak adlandırılan bu zevâtın Bayezid-i Bistamî̀ye olan bağlılıkları kaynaklarda açık şekilde belirtilir.

\section{Sonuç}

$\mathrm{Bu}$ çalışma ile $\mathrm{Hz}$. Peygamber'in vefatından çok daha sonra Müslüman olan Türklerin, Peygamber'i görmeden ona aşk ile bağlanarak O’nun hırkasına varis olan Veysel Karanî ve bu hırkanın sonraki sahibi Bayezid Bistamî́yi pir edindikleri gösterilmiştir. Söz konusu hırka, Cumhuriyet'in ilanına kadar Zile'deki Bayezidiyye Hanikâhı'nda korunmuş, buradan Ankara'daki Etnoğrafya Müzesi'ne nakledilmiştir. Türklerin Müslümanlığı üzerindeki Üveysî-Bistamî etkisini, Satuk Buğra Han'dan itibaren İslamlaşmanın bütün merhalelerinde görmek mümkündür. Hanefî-Maturidî mezheb ve akaidi çerçevesinde gelişen bu İslamlaşmanın izlerini tarihi kaynaklarda müşahede etmek mümkündür. Veysel Karanî́nin peygambere ve onun ehl-i beytine olan sevgisi ve bağılığı, Müslümanlığı kabul eden Türkistan ve Horasan ahalisi ile Farsîlerde de görülür. Tokat-Zile'deki Bayezidiyye Hânikâhı'nda medfûn bulunan Cemâlüddin Musa Zilî́nin, Kalenderiyye'yi bir tarikat olarak teşkilatlandıran Cemâlüddin Sâvî ile aynı kişi olduğu ve Kutbüddin Haydar ile aynı çevreden yetiştiği, belki de baba-oğul ya da aynı kişi olduğu ortaya konulmuş, onun ahfadının Şeyh Osman-ı Velî ile olan bağlarının da yüzyıllar boyunca devam ettiği gösterilmiştir. Ahmed el-Bedevî́nin çocuklarının da Anadolu'da bulunduğu ve Kadirî-Rıfâî çerçevede değerlendirilen bu kişiden

\footnotetext{
${ }^{73}$ Bkz. Hamid Algar, "Nakşibendiye", TDViA, C. XXXII, İstanbul: TDV Yayınları, (2006), s. 335-342; Algar, "Gücdivanî, Abdülhalik", TDVIA, C. XIV, İstanbul: TDV Yayınları, (1996), s. 169-171; Uludağ, "Bâyezîd-i Bistâmî", TDVIA, C. V, İstanbul: TDV Yayınları (1992), s. 238-241. Ayrıca bkz. Hasan Kâmil Yılmaz, Altın Silsile, İstanbul 2014.
}

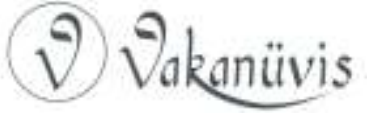


hareketle Şeyh Osman'ın Abdülkadir Geylanî'nin torunu olabileceği fikri öne sürülmüştür. Ahmed Bedevî gibi "el-mülessim/peçeli" bir tecerrüd hâlinde olan biriyle "el-mücerred/çıplak/yalnız" olarak tecerrüd halindeki bir kişinin dünürlügü̈, tasavvuf dünyasına ait yolların aslında çok girift bir yapıda olduğunu gösterdiği gibi, bu yapının sınıflara ayrılarak anlatılmasıyla beraber ortaya konan genellemeler, hatalı yorumlara sebep olmuştur.

Osmanlıların ve diğer beyliklerin kurucularının atalarının, tasavvuf erbabıyla yakın akrabalık içerisinde oldukları, Veysel Karanî-Bayezid-i Bistamî evladından olarak Emirce İsmail Sultan, İsmail Dede Karkın (Şeyh Nu'man), Cemâlüddin Musa, Hacı Bektaş Velî, Celalüddin Karatay, Karaca Ahmed, Tapduk Emre ve Yunus Emre gibi BistamîKalenderî-Haydarî olarak tanımlanan sınıfın içinde yer aldıkları, bununla beraber Ebu'I-Vefa Bağdadî, Abdülkadir Geylanî ve Ahmed erRıfâî́nin tasavvuf görüşlerinin de bunlardan çok farklı olmadığı da gösterilmeye çalışıldı. Osmanlıların Anadolu'da bilinen ilk atası Şeyh Nu'man, Bayezid-i Bistâmî şeyhi olarak geldiği Anadolu'da önce Ebu'lVefa Bağdadî'ye, daha sonra ise Ahmed er-Rıfâîye bağlanmış, onun torunu Baba Illyas da bir Vefaî-Rıfâi babası sıfatıyla Anadolu'da etrafına kalabalık bir Türkmen kitlesi toplamıştı. Emirce (Emir-i Çin) Sultan, Cemalüddin Musa Paşa ve Hacı Bektaş Velî gibi Bayezidiyye Tarikatı'nın Kalendermeşrep anlayışına sahip temsilcileri, bir yandan XIII. yüzyılın sonunda Selçuklu iktidarının yerini alacak olan idarenin temellerini, Moğollara karşı cihad anlayışı çerçevesinde atarlarken, öte yandan Ahmed el-Bedevî elinden Mısır'da Sultan Baypars ile başlayan Memlük hâkimiyetinin tesisini sağlamışlardı. Bunun başarılması, ancak fütüvvet anlayışıyla mümkün olabilmişti. XIII. yüzyılın ikinci yarısındaki siyasi gelişmelerin önemli amillerinin tamamı Kalenderî anlayışa sahip kişilerdi. Bunların torunları, XIV. yüzyıldaki Balkan fütuhatında çok önemli roller üstlendiler. Örneğin Karaca Ahmed, Celalüddin Karatay'ın kardeşi Rum Paşa'nın oğlu iken, Murad Hüdâvendigâr'ın Malkara'da adına bir zaviye vakfı kurduğu Ahi Musa, bölgedeki tüm ahilere berat veren bir ahi merkezinin şeyhi olarak Kalenderîliğin ve ahiliğin teşkilatlandırılmasında en önemli pay sahiplerinden biri durumundaki Cemalüddin Musa Paşa'nın torunlarından biri olarak ön plana çıkmıştır. $\mathrm{Bu}$ tespitler, Osmanlıların Timur karşısındaki yenilgisinden sonraki toparlanışının neden Kızılırmak-Yeşilırmak havzasındaki eski

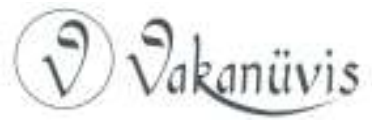


Danişmediyye bölgesi olduğunu da açıklığa kavuşturur. Osmanlılarda sultan olacak şehzâlederin Amasya'da yetiştirilmesi de bu bağlamda ele alınmalıdır. Manisa'nın bu konuda Amasya'nın önüne geçmesi, çok daha sonraları, Kanunî döneminden itibaren olmuştur.

Bundan sonra, literatüre yerleşen Sünni (Ortodoks)-Heterodoks ayrımı yerine, tasavvuf erbabını zaman zaman eleştiren grupları "taassub ehli" olarak nitelendirmenin daha doğru bir yaklaşım olacağı önerilmelidir. Taassub ehlinin, sünnî olarak tavsifi gerçekten çok sakıncalı görünmektedir. İbn Ârabî’ye "şeyhü'l-ekfer" diyenlerle Kalenderîlere birçok günah isnad edenlerin tamamı, sünnî akaide uymadan, "şeriat, zahire bakar"74 gibi eksik tanımlı bir doktrine bağlı olarak taassubun içine düşmüşlerdir. Yavuz Sultan Selim tarafından Şam'da İbn Arabî adına tescil ettirilen vakfiyede geçen şu ifadeler, durumu en güzel şekilde anlatır:

“...çünkü heva ve hevesinin mağlubu olan kinci müteassıp gürûh, söz oklarıyla onları yaralamaktan çekinmiyorlardı. Kendileri cevher ile araz arasını farkedemeyen, ilim davasında olan cahillerdir. Sözlerinin manasını anlamaktan âciz, ne dediğini bilmeyen bu cahil gürûh; Muhiyiddin-i Â'rabî'yi kendi garazkâr sözlerine hedef tutmuşlardı. Onun hakkında rastgele konuşuyorlardı. Ancak ilâhî ismete mazhar olmuş olan bundan hariçti ve onlar da zaten pek azdır. Kişi cahili olduğu şeyin düşmanıdır. Ondan ayrılıp uzaklaşmak ister. Onu anlayıp kıymetini bilecek kabiliyeti yoktur. Bir şeyi bilmek için tenkid edebilmek lâzımdır. Altın'da hiç bir kusur yoktur, kusur onu döğendedir. Bu adamlar eğer kendi kusurlarıla meşgul olsalar da geçmiş günahlarına nedamet yaşları dökseler, onlar için çok iyi ve hayırlı olurdu. Belki sevaba bile kavuşurlardı..."75

Asabiyet ile aynı kökten geldiği düşünülen taassub ${ }^{76}$, fanatizmbağnazlık kavramları ile eş anlamlıdır. "Yanlışlığı ortaya çıkmadığı sürece hak olduğuna inandığı şeye göre davranma" manasındaki

\footnotetext{
74 İbrahim Kâfî Dönmez, "Zahir", TDVIA, C. XLIV, İstanbul 2013, s. 85-87.

75 Bkz. VGMA, D. 2113, s. 259/47. Kalenderîler hakkındaki eleştiriler için bkz. Eyüp Öztürk, ibnü's-Serrâc ve Müvelleh Dervişler, Ankara Üniversitesi, Sosyal Bilimler Enstitüsü, İslam Tarihi ve Sanatları Anabilim Dalı, Doktora Tezi, (2011), s. 98; G. Antonia Menavino, Türklerin Hayatı ve Adetleri Üzerine Bir Inceleme, (Çev. Harun Mutluay), İstanbul 2011, s. 55.

${ }^{76}$ Mustafa Çağrıcı, "Taasub”, TDVIA, C. XXXIX, İstanbul 2010, s. 285-286.
}

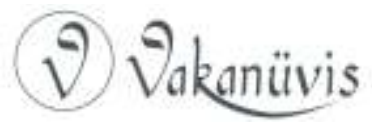


sebattan farklıdır. Şeriatın zahire bakmasından kasıt esasen beyana bakması olmalıdır. Nas hükmünde olan bir kelamı alenen inkâr ettiğini beyan etmediği sürece, her kişi Müslüman kabul edilir. Matûridî ve Eş’arî akaidine göre, günah işleyen kişinin dinden çıktığına değil, günahkâr olduğuna hükmedilebilir ${ }^{77}$.

Her ne kadar haram ve günah olduğu sabit olan davranışta devamlılık, bir hükmü gerektirse de hüküm taassub ehlinin değil, Allah'ındır. Bundan dolayıdır ki melâmi-kalenderî anlayışa sahip olan derviş, "biz içeriz, bize yoktur vebâli" demeden önce, tanrı adına hüküm veren taassub ehlini uyarır: "senin aklın ermez, bu başka hesap!". Aslında burada kınayıcı taassub ehli, "ne yaparsan yap, benim kendimi kınadığım kadar beni kınayamazsın" düsturunca, kendi günahları ve hatalarıyla meşgul olmaya davet edilir ${ }^{78}$. Sonuçta, Allah kelâmı bir konuda çok nettir: "insan zayıf yaratılmıştır", "doğrusu insan çok câhildir", "doğrusu insan, çok nankördür", "insan pek acelecidir", "gerçekten insan pek zâlimdir", "gerçekten insan çok cimridir", "insan, tartışmaya her şeyden daha çok düşkündür", "doğrusu insan hırslı ve huysuz yaratılmıştır", "doğrusu insan hep zarardadır"79. "Siz günah işlemeseydiniz, Allah sizi helak eder ve yerinize, günah işleyip, peşinden tövbe eden kullar yaratırdı"80 şeklindeki hadisi, günaha teşvik olarak gördükleri için "uydurmadır" diyenler, belki de nefslerine son derece hâkim, bilerek veya bilmeyerek günah işlemekten berî, adeta melekleşmiş kişilerdir. Burada insanın günaha düşmesinin çoğu zaman kaçınılmaz olduğu, aynı günahı ısrarla sürdürmesinin dışında Allah'ın rahmet kapısının herkese açık olduğu anlaşılmalıdır. Kendisinden başka herkeste kusur gören gözlerin sahibi, kendisinin cennete gireceğinden, çok az bir ihtimal dışında neredeyse emin gibidir. Ancak kişilerin kendileri hakkındaki bu tarz düşünceleri, "ben Adem'den daha hayırlıyım" diyen şeytanın düşünce yapısıyla ne kadar da çok benzerlik taşır. Herhalde insanlar arasında en akılsız olanı, kendi zararına bakmaksızın, başkalarının hayatı hakkında hüküm vereni olmalıdır.

\footnotetext{
77 Turgut, "Sarı Saltuk, Ona Ait Türbeler ve Ejderha Kültü’ne Dair", s. 145-167.

78 Nihat Azamat, "Melâmet", TDViA, C. XXIX, İstanbul 2004, s. 24-25; ayrıca bkz. "Melâmiyye", s. 29-35.

79 Kur'an-ı Kerim, 4/28, 33/72, 14/34, 17/11, 67, 100, 22/66, 42/48, 43/15, 100/6, 21/37, 18/54, 70/19.

80 Müslim, Tevbe/9.
}

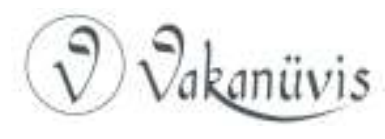


Pek çok Osmanlı belgesinde eli kalem tutanların kalemlerinden ve belli ki dillerinden düşürmediği "hakir" sözcüğü, melâmî-kalenderî anlayışın bir tezahürüdür. Hakir kelimesi, hakarete uğramış manasındadır. Öyle ki zamanın kutupları olarak kabul edilen zevât, kendilerini veliliğin en üst mertebesinden ziyade, "mecnun"luğun ve "meczub"luğun dibinde gördüklerinden, tarihi belgelere dahi bu sıfatlarla kaydedilmişlerdir. Ancak toplumların bu tarz bir cezbe içerisinde olanlara, adeta "deliliğe övgü"ler sunarcasına saygı gösterdikleri ve onları kendilerine lider seçtikleri müşahede olunur. Bu denli bir tevazunun, delilere teklif olmayacağı yönündeki şer'i hükümlere uygun olarak, zahirî anlamıyla yorumlanması, kuşkusuz sosyal-siyasetin mimarları durumundaki meşâyihin düşünce yapısının anlaşılmasına engeldir. Kalenderî/Haydarîmeşrep dervişlerin, "güzelçirkin aramayıp, gönlüne bir eğlence isteyen" kişiler olarak algılanmaları, iman ve ibadetler konusunda "riya"ya düşmeme prensibiyle yakından ilgili olmalıdır. İstediğini cennete, istemediğini ise cehenneme koyan, dünya hayatında anlaşamadığı kişilerle cennette bir arada bulunma ihtimalini dahi tasavvur edemeyen sıradan insandan farklı olarak bir Kalenderînin, hiçbir konuda iddia sahibi olmayıp, teslimiyetini "cennet cennet dedikleri, birkaç köşkle birkaç huri, isteyene ver sen anı/onu, bana seni gerek seni" sözleriyle ifade ettiği için, her halde sünnetin dışına çıktığına hükmedilemez. Tarihî metinlerde şer'î hükümlere uymadıkları yönünde anlatılar, "Kalenderî" postuna bürünmüş, heva ehli kişileri işaret edebileceği gibi, taassup ehlinin Allah adına hüküm verme cüretini de ifade ediyor olabilir. Bunların hangisinin geçerli olduğu asla bilinemeyeceğinden, bakış açılarına göre varılan sonuçlar da farklı olacaktır.

"Kalenderîler şarap içer miydi? Esrar kullanırlar mıydı? Zinayı günahtan saymazlar mıydı?” gibi pek çok soruya verilebilecek en güzel cevap; Kalenderîlerin, kişilerin kusurlarına gözlerini kapadıklarından, bu tarz sorularla meşgul olmadıklarını beyan etmektir. Kendileri bu tarz bir soruyla karşılaştıklarında verdikleri tipik cevaplardan biri şu olsa gerek: “Nesimîye sordular: 'O yâr ile hoş musun?', hoş olayım, olmayayım, $O$ yâr benim kime ne?". Kişinin kendi günahlarının farkında olup bundan nadim olurken, başkalarının haram şeylerle meşgul olduğunu zannettiği ya da müşahede ettiği durumlarda da "örtücü" bir tavır sergilemesi gerektiği aşikârdır. Onların böyle bir prensiple hareket

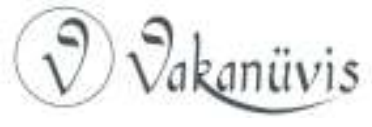


etmeleri, "emr-i bi'l-ma'ruf, nehy-i a'ni'l-münker" ilkesindeki hedefe en kısa yoldan varılmasını da sağlamaktaydı. Herkesin Kalenderî olduğu bir toplumda, bunun kendiliğinden gerçekleşmesi mukadderdi. Onların fütüvvet ehlinin pirlerinden olarak genç erkek ve kadınlarla yakından ilgilenmeleri bile "cemalperestlik" adı altında -maalesef- farklı yorumlanmıştır. Halbuki burada kastedilen şey; fütüvvetten, ahilikten başka bir şey değildir. Merkezîleşme temayülü gösteren devletin, kendisiyle aynı asabiyete mensub olmayanları devşirirken, devlet çatısına en uygununu, yakışanını ve cevvalini seçmesi de bu bağlamda değerlendirilmelidir. Kör olanların asla erişemediği, topal ve sağır olanların ise nadiren muvaffak olduğu emaret/saltanatın hizmetinde olanların da içinden çıktıkları toplumların en gürbüzlerinden olmasına farklı anlamlar yüklemek, olayları ve olguları saptırmaktan başka bir şey olmasa gerektir. Bu bağlamda, "oğlan" kelimesinin de istismar edilerek farklı yorumlandığına burada değinmek gerekir. Bu kelime, kız-erkek ayırd etmeksizin bütün genç insanlar için kullanılmaktaydı. O dönemin önemli ailelerinin kızlarına Oğulpaşa, Oğulşah gibi isimler dahi koydukları bilinmektedir ${ }^{81}$.

Bayezidiyye olarak isimlendirilen tarikat ile onun bir kolu durumundaki Bektaşiyye'nin, Horasan'da yaygın olduğu vechle Hanefî mezhebinden ve Matûridî akaidine bağlı olarak değerlendirilmesi gerekir. Bektaşiyye ve Bedeviyye içindeki "Şii" anlayışın ise, sonraki yüzyıllarda ortaya çıktığı anlaşılmaktadır. Hacı Bektaş Velî’ye nisbet edilen sünnî akaide uygun dinî eserlerin, sonradan onun adına yazıldığı görüşünün kabul edilmesi, bu belgeler ışığında artık mümkün değildir. Gerek o eserlerin, gerekse bu vakıf belgelerinin sonraki yüzyıllarda sünnî görüşe sahip kişiler tarafından uydurulduğunu söylemek, "mesnedsiz" bir görüş ortaya atmanın yanısıra, bunu yapan kişilerin öngörü sahibi olduklarını ve adeta günümüzdeki tartışmaları önceden tahminle bilgileri tahrif ettiklerini kabulü gerektirecektir. İbn Battuta'nın Anadolu'da yaşayan Müslümanların ekserisinin "Hanefî" olduklarını belirtmesi, Osman Gazi'nin kayınpederi olması kuvvetle muhtemel olan Molla Hattab'ın Matûridî akaidine bir şerh yazması ve

81 "Oğlancılık", "zina”, "içki, esrar kullanımı", kadim zamanlardan beri her toplumda görülen olgulardan olup, burada karşı çıkılan şey, sosyal siyasete yön veren meşâyih için bu tarz ithamların ortaya atılmasıdır.

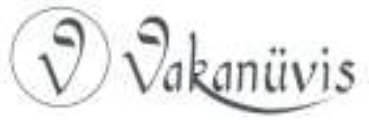


Osman Gazi'nin de bir vakıf belgesi dolayısıyla "hanefi" olup, adını Şeyh Osman-ı Velî'den alması gibi bilgi ve tespitler, bu mesnedsiz iddiadan artık vazgeçilmesini gerektirir ${ }^{82}$. Batılı kaynaklarda Yavuz Sultan Selim'e izafe edilen "Haydarî" portre, her ne kadar sünnî bir İslam halifesine yakıştırılamamış olsa da Kalenderî/Haydarîlerin Hanefî mezhebine bağlııkları ve Osmanlıların atalarıyla olan sıhriyeti, bu portrenin gerçekten de Yavuz Sultan Selim'e ait olabileceğini düşündürür. Yukarıda da gösterildiği üzere, Kızılırmak-Yeşilırmak havzası içinde yer alan Kalenderî merkezlerinin tevliyet ve meşihatinin, XIII. yüzyıldan en azından XVI. yüzyılın sonlarına kadar evlatlık üzere kesintisiz şekilde tasarruf edildiği ve Sultan ile Şah arasındaki siyasi gerginliğin de bu durumu değiştirmediğinin altı burada yeniden çizilmelidir. Bayezid Bistamî'den kalan hırkanın, 1944'e kadar bölgedeki en kutsal eşyalar arasında yer alması, bu durumun bütün yüzyıllar boyunca sürdüğünü de düşündürür. Ez-cümle, bunca söz, uğraş ve hükümden sonra çekilen "Hû", zahirde yorgunluğun ünlemi iken, ancak beyan ile Rabb'a yakarış zuhura gelmiş olur. Bu beyanın, tanrı adına hüküm veren taassup ehlinin huzurunda yapılması gibi bir zorunluluk da söz konusu değildir.

\section{KAYNAKÇA}

\section{ARŞiV KAYNAKLARI}

BOA. Tahrir Defteri (TD.) 75.

Tapu Arşiv Dairesi Başkanlığı, Tapu Tahrir Defteri, Evkaf (TADB. TTD. EV. 560).

82 VGMA, D. 574, s. 43/99; i. Hakkı Uzunçarşılı, “Gazi Orhan Bey Vakfiyesi 724 Rebiüelevvel-1324 Mart", Belleten, C. 5, S. 19, (Temmuz 1941), s. 277-288; Uzunçarşılı, "Gazi Orhan Bey Vakfiyesi", Osmanlı Hanedanı Üstüne Incelemeler-Seçme Makaleler, 2, İstanbul: YKY 2012, s. 37-49; Uzunçarşılı, "Orhan Gazi'nin oğlu Süleyman Paşa İçin Tertip Ettirdiği Vakfiyenin Aslı", Osmanlı Hanedanı Üstüne Incelemeler-Seçme Makaleler, 2, s. 50-65; Hakan Yılmaz, "Geyikli Baba'nın İnegöl'e Yerleşmesi, Orhan Gazi ile İlişkisi ve Heterodoksluğu Yönündeki İddiaların Kesin Deliller Işığında Çürütülmesi", Uluslararası Inegöl Tarihi ve Kültürü Sempozyumu (14-16 Ekim 2016), İstanbul 2017, s. 472-476; İbn Battuta, Seyahatnâme, (Çev ve İnc. A. Sait Aykut), İstanbul 2000, s. 402; Turgut, "Orhan Gazi Dönemi ve Vakıfları", s. 395; Turgut, "Renklerin Efendisi", s. 101118.

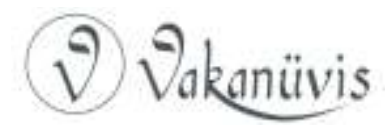


Tapu Arşiv Dairesi Başkanlığı, Tapu Tahrir Defteri, Evkaf (TADB. TTD. EV. 554).

Tapu Arşiv Dairesi Başkanlığı, Tapu Tahrir Defteri, Evkaf (TADB. TTD. EV. 555).

Tapu Arşiv Dairesi Başkanlığı, Tapu Tahrir Defteri, Evkaf (TADB. TTD. EV. 564).

Tapu Arşiv Dairesi Başkanlığı, Tapu Tahrir Defteri, Evkaf (TADB. TTD. EV. 565).

Tapu Arşiv Dairesi Başkanlığı, Tapu Tahrir Defteri, Evkaf (TADB. TTD. EV. 571).

Tapu Arşiv Dairesi Başkanlığı, Tapu Tahrir Defteri, Evkaf (TADB. TTD. EV. 579).

Tapu Arşiv Dairesi Başkanlığı, Tapu Tahrir Defteri, Evkaf (TADB. TTD. EV. 580).

Tapu Arşiv Dairesi Başkanlığı, Tapu Tahrir Defteri, Evkaf (TADB. TTD. EV. 583).

Tapu Arşiv Dairesi Başkanlığı, Tapu Tahrir Defteri, Evkaf (TADB. TTD. EV. 585).

Tapu Arşiv Dairesi Başkanlığı, Tapu Tahrir Defteri, Evkaf (TADB. TTD. EV. 584).

Vakıflar Genel Müdürlüğü Arşivi (VGMA, D. 574).

Vakıflar Genel Müdürlüğü Arşivi (VGMA, D. 577).

Vakıflar Genel Müdürlüğü Arşivi (VGMA. D. 582).

Vakıflar Genel Müdürlüğü Arşivi (VGMA. D. 733).

Vakıflar Genel Müdürlüğü Arşivi (VGMA. D. 1966).

Vakıflar Genel Müdürlüğü Arşivi (VGMA, D. 2113).

\section{Kitap ve Makaleler}

75 Numaralı Gelibolu Livâsı Mufassal Tahrir Defteri (925/1519): I, (Haz. A. Sivridağ vd.), Ankara: Devlet Arşivleri Yayınları, 2009.

Ahmed Eflakî: Menâkıbü'l-Kudsiyye, Ariflerin Menkıbeleri, (Çev. Tahsin Yazıcı), İstanbul: Kabalcı Yayınları, 2012.

Algar, Hamid: "Gücdivanî, Abdülhalik", Türkiye Diyanet Vakfı İslam Ansiklopedisi (DIA), 1999, XIV, s. 169-171.

Algar, Hamid: "Nakşibendiye", Türkiye Diyanet Vakfı İslam Ansiklopedisi (DIA), 2006, XXXII, s. 335-342.

Ayverdi, E. Hakkı: "Orhan Gazi Devrinde Mimari", Ankara Üniversitesi Ilahiyat Fakültesi Yıllık Araştırmalar Dergisi, I, (Ankara 1956), s. 115-197.

Ayverdi, E. Hakkı: Osmanlı Mimarisinin Ilk Devri, İstanbul: Fetih Cemiyeti Yayınları, 1966.

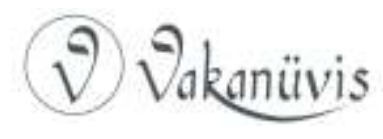


Azamat, Nihat: "Melâmet", Türkiye Diyanet Vakfı İslam Ansiklopedisi (DiA), 2004, XXIX, s. 24-25.

Babinger, F.-Köprülü, M. Fuad: Anadolu'da Islâmiyet, (Haz. Mehmet Kanar), İstanbul: İnsan Yayınları, 1996.

Barkan, Ö. L.-Meriçli, Enver: Hüdâvendigar Livâsı Tahrir Defterleri, I, Ankara: TTK Yayınları, 1988.

Barkan, Ö. Lütfi: “Osmanlı İmparatorluğu’nda Bir İskân ve Kolonizasyon Metodu Olarak Vakıflar ve Temlikler I: İstilâ Devirlerinin Kolonizatör Türk Dervişleri ve Zâviyeler", Vakıflar Dergisi, II (Ankara 1942), s. 279-386.

Baş, Derya Çakır: "Bedeviyye”, Türkiye'de Tarikatlar, Tarih ve Kültür, (Ed. Semih Ceyhan), İstanbul: ISAM Yayınları, 2015, s. 547-608.

Ceyhan, Semih: "Şems-i Tebrîzî", Türkiye Diyanet Vakfı íslam Ansiklopedisi (DIA), 2010, XXXVIII, s. 511-516.

Çağrıcı, Mustafa: "Taasub", Türkiye Diyanet Vakfı islam Ansiklopedisi (DiA), 2010, XXXIX, s. 285-286.

Çal, Halit: "Şeyh Nasreddin (Nusret) Türbesi", Türk Tarihinde ve Kültüründe Tokat Sempozyumu (2-6 Temmuz 1986), Bildiriler, Ankara: Tokat Valiliği Yay., 1987, s. 427-461.

Danişmend, İ. Hami: İzahlı Osmanlı Tarihi Kronolojisi, V, İstanbul: Türkiye Yayınları, 1971.

Dönmez, İbrahim Kâfî: "Zahir", Türkiye Diyanet Vakfı islam Ansiklopedisi (DIA), 2013, XLIV, s. 85-87.

Duran, Remzi: Selçuklu Devri Konya Yapı Kitabeleri (İnşa ve Ta'mir), Ankara: Konya Turizm Der. Yayınları, 2001.

Erdoğru, M. Akif: Kanuni Sultan Süleyman Devri Aydın ili Evkâf Defteri, İzmir: Ege Üniversitesi Yayınları, 2016.

Eyice, Semavi: "Hacı Hamza Bey Mescidi ve Türbesi", Türkiye Diyanet Vakfı Islam Ansiklopedisi (DIA), 1996, XIV, s. 478-479.

Göde, Kemal: "XIV. Yüzyılda Tokat/Eratnalılar Hâkimiyetinde Tokat", Türk Tarihinde ve Kültüründe Tokat Sempozyumu, (2-6 Temmuz 1986). Ankara: Gelişim Matbaası. 1987, s. 17-22.

Gökbilgin, M. Tayyip: "Tokat”, MEB Islam Ansiklopedisi, 1979, XII/1, s. 401411.

Gülten, Sadullah: "Tahrir Defterlerine Göre Anadolu'da Kalenderîler ve Haydarîler", Tarih Araştırmaları Dergisi, C. 31/52, (2012), s. 35-53.

Hünkâr Hacı Bektaş Velî Velâyetnâmesi: (Yay. Haz. H. Duran-D. Gümüşoğlu), Ankara: Türkiye Diyanet Vakfı Yayınları, 2010.

Ibn Battuta, Seyahatnâme, (Çev ve İnc. A. Sait Aykut), İstanbul: YKY, 2000.

İbn Bibî: El-Evâmirü'l-Âlaiyye fi'l-Umûri'l-Alâ'iyye (Selçuknâme), II (Çev. Mürsel Öztürk), Ankara: TTK Yayınları, 2010. 
Kahraman, Nurfeddin vd.: "İsa Sofu Türbesi: Tezyinatı ve Türklerin İslamlaşma Süreci Açısından Değerlendirilmesi", Türk Kültürü Incelemeleri Dergisi. 41, (2019), s. 121-154.

Kara, Mustafa: "Ahmed el-Bedevî", Türkiye Diyanet Vakfı islam Ansiklopedisi (DiA), 1989, II, s. 47-48.

Kara, Mustafa: "Bedeviyye", Türkiye Diyanet Vakfı Islam Ansiklopedisi (DiA), 1992, V, s. 318-319.

Karaca Ahmed Sultan Menâkıbnâmesi: (Haz. D. Gümüşoğlu), İstanbul: Zinde Yayınevi, 2013.

Kavak, Abdulcabbar: "Şeyh Ebubekir Abdülaziz es-Sincarî (ö. 602/1205) ve Kâdiriyye Tarikatı'nın Kuzey Irak'taki Erken Dönem Faaliyetleri", Akademik Bakış, 54, (2016), s. 147-160.

Koç, Mustafa: "Eski Anadolu Türkçesi Karışık Dilli Metinlerinden Barak Baba Manzumesi", Hacettepe Üniversitesi Türkiyat Araştırmaları Dergisi, 28 (2018), s. 281-300.

Konyalı, I. Hakkı: Abideleri ve Kitabeleri ile Konya Tarihi, Konya: Yeni Kitap Basımevi, 1964.

Köprülü, M. Fuad: Türk Edebiyatında Ilk Mutasavvıflar, (Yay. Haz. Orhan Köprülü), Ankara: Diyanet İşleri Başkanlığı Yayınları, 1976.

Menavino, G. Antonio: Türklerin Hayatı ve Adetleri Üzerine Bir Inceleme, (Çev. Harun Mutluay), İstanbul: Dergah Yayınları, 2011.

Muhammed b. Ali b. Es-Serrac: Tuffahü'l-Ervâh ve Miftahü'l-irbah, (Haz. N. Gürkan-M. N. Bardakçı-M. S. Sarıkaya), İstanbul: Kitap Yayınevi, 2015.

Ocak, A. Yaşar: "Emirci Sultan ve Zaviyesi, XIII. Yüzyılın İlk Yarısında Anadolu (Bozok)'da Bir Babaî Şeyhi: Şerefüddin İsmail b. Muhammed", iÜEF, Tarih Enstitüsü Dergisi, 9, (1978), s. 130-208.

Ocak, A. Yaşar: Osmanlı Toplumunda Tasavvuf ve Sûfiler, Ankara: TTK Yayınları, 2005.

Ocak, A. Yaşar: Osmanlı Imparatorluğu'nda Marjinal Sûfilik: Kalenderiler (XIV-XVII. Yüzyıllar), Ankara: TTK Yayınları, 2010.

Ocak, A. Yaşar: Ortaçağlar Anadolu'sunda İslam'ın Ayak izleri, Selçuklu Dönemi. İstanbul: Kitap Yayınevi, 2011.

Ocak, Ahmet Yaşar: Sarı Saltık: Popüler İslam'ın Balkanlardaki Destanî Öncüsü (13. Yüzyıl), İstanbul: Kitap Yayınevi, 2016.

Önder, Mehmet: Mevlana Şehri Konya, İstanbul: Konya Turizm Der. Yay., 1971.

Önkal, Hakkı: "Üç Selçuklu Türbesi Hakkında Notlar", DEÜ, Ilahiyat Fakültesi Dergisi, II (1985), s. 31-48.

Özcan, Hüseyin-Gönenç, C. Sezen: "Yazılı ve Sözlü ortamlardaki Karaca Ahmet Sultan Menkabelerinin Karşılaştırılması". Turkish Studies, 10/4, (2015), s. 717-746.

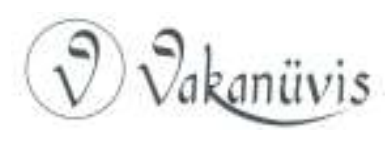


Özköse, Kadir: "Tokat'ta Tasavvuf Kültürü", Gazi Osmanpaşa Üniversitesi, Tokat Tarihi ve Kültürü Sempozyumu, (25-26 Eylül 2014), Bildiriler, C. III. Tokat: Valilik Yayınları, 2015, s. 79-102.

Öztürk, Eyüp: ibnü's-Serrâc ve Müvelleh Dervişler, Ankara Üniversitesi, Sosyal Bilimler Enstitüsü, İslam Tarihi ve Sanatları Anabilim Dalı. Doktora Tezi, 2011.

Şahin, Haşim: "Selçuklu ve Erken Osmanlı Döneminde Vefâiyye Tarikatı". Türk Kültürü ve Hacı Bektaş Veli Araştırmaları Dergisi, 70, (2014), s. 39-54.

Şahin, Haşim: Dervişler ve Sufi Çevreler, Klasik Çağ Osmanlı Toplumunda Tasavvufi Şahsiyetler, İstanbul: Kitap Yayınevi, 2017.

Taşğın, Ahmet: Dediği Sultan ve Menâkıbı (Konya ve Çevresinde Ahmet Yesevî Halifelerinin (izleri), Konya: Çizgi Kitapevi, 2013.

Taşğın, Ahmet-Solmaz, Bünyamin: "Hacl Bektaş ve $\mathrm{Hacl}$ Toğrul Karşılaşması: Güvercin ve Doğan Donuna Bürünme", Turkish Studies, V. 7/1, (2012), s. 105-129.

Taşğın, Ahmet: "Yezidiyye", Türkiye Diyanet Vakfı Islam Ansiklopedisi (DiA), 2013, XLIII, s. 525-527.

Tosun, Necdet: "Karaca Ahmed Hakkında Yeni Bir Kaynak ve Meçhul Kalmış Bilgiler", Uluslararası Üsküdar Sempozyumu V, (1-5 Kasım 2007), C. II, (Ed. C. Yılmaz). İstanbul: Üsküdar Belediyesi Yay., 2008, s. 323-328.

Tosun, Necdet: "Üveysilik", Türkiye Diyanet Vakfı İslam Ansiklopedisi (DiA), 2012, XLII, s. 400-401.

Turan, Osman: "Selçuklu Devri Vakfiyeleri-III, Celâleddin Karatay, Vakıfları ve Vakfiyeleri", Belleten, C. XII/45, (1948), s. 17-170.

Turan, Osman: "Selçuklu Türkiye'si Din Tarihi'ne Dair Bir Kaynak: Fustatü'l'Adale fî kava'idi's-Saltana", 60. Doğum Yılı Münasebetiyle Fuad Köprülü Armağanı, İstanbul: Ankara Üniversitesi DTCF Yay., 1953, s. 553-564.

Turgut, Vedat: "Hamidoğulları ve Tekeoğulları'nın Menşei ve Vakıflarına Dair", Journal of Turkish Studies/Türklük Bilgisi Araştırmaları, (Ed. Cemal Kafadar-Gönül A. Tekin), 46 (2016), s. 403-432.

Turgut, Vedat: "Vakıf Belgelerine Göre Osmanlı Devleti'nin Kuruluş Dönemi Aileleri II: Âl-i Timurtaş Paşa”, Osmanlı Araştırmaları/The Journal of Ottoman Studies, 53 (2019), s. 51-120.

Turgut, Vedat: "Orhan Gazi Dönemi ve Vakıfları", Uluslararası Orhan Gazi ve Kocaeli Tarihi-Kültürü Sempozyumu Bildirileri-V, C. I, Kocaeli: Belediye Yayınları. 2019, s. 391-474.

Turgut, Vedat: "Renklerin Efendisi", Uluslararası Milli Mücadelede Servetiye Cephesi ve Kocaeli Tarihi-Kültürü Sempozyumu Bildirileri-VI, C. I, Kocaeli: Belediye Yayınları, 2020, s. 101-118. 
Turgut, Vedat: "Sarı Saltuk, Ona Ait Türbeler ve Ejderha Kültü'ne Dair", Rumeli'de Osmanlı Vakıfları Üzerine Araştırmalar: Bulgaristan, (Ed. A. Kala vd.), istanbul: Vakar Yayınları, 2020, s. 145-167.

Turgut, Vedat: Osmanlı Devleti'nin Kuruluş Coğrafyasında Vakıflar ve Şehirleşme, Bilecik: Şeyh Edebali Üniversitesi Yayınları, 2015.

Türkel, Ergin: 16. Yüzyılda Kütahya Sancağı Vakıfları (Emet, Denizli, Uşak, Burdur). Bilecik Şeyh Edebali Üniversitesi, Sosyal Bilimler Enstitüsü, Doktora Tezi, 2017.

Uludağ, Süleyman: "Bâyezîd-i Bistâmî", Türkiye Diyanet Vakfı islam Ansiklopedisi (DIA), 1992, V, s. 238-241.

Uludağ, Süleyman: "Adî b. Müsafîr", Türkiye Diyanet Vakfı İslam Ansiklopedisi (DiA), 1988, I, s. 381.

Uludağ, Süleyman: "Mücerred", Türkiye Diyanet Vakfı islam Ansiklopedisi (DiA), 2006, XXXI, s. 447-448.

Uzunçarşılı, i. Hakkı: "Osmanlı Tarihine Ait Yeni Bir Vesikanın Ehemmiyeti ve İzahı ve Bu Münasebetle Osmanlılarda ilk Vezirlere Dair Mütalaa", Osmanlı Hanedanı Üstüne Incelemeler, Seçme Makaleler, 2, İstanbul: YKY., 2012, s. 2532.

Uzunçarşılı, i. Hakkı: "Gazi Orhan Bey Vakfiyesi 724 Rebiüelevvel-1324 Mart", Belleten, C. 5, S. 19, (Temmuz 1941), s. 277-288.

Uzunçarşılı, I. Hakkı: "Gazi Orhan Bey Vakfiyesi", Osmanlı Hanedanı Üstüne incelemeler-Seçme Makaleler, 2, i̇stanbul: YKY 2012, s. 37-49.

Uzunçarşılı, i. Hakkı: “Orhan Gazi'nin oğlu Süleyman Paşa İçin Tertip Ettirdiği Vakfiyenin Ası", Osmanlı Hanedanı Üstüne incelemeler-Seçme Makaleler, 2, s. 50-65.

Yazıcı, Tahsin: "Cemâleddin-i Sâvî", Türkiye Diyanet Vakfı islam Ansiklopedisi (DIA), 1993, VII, s. 313-314.

Yazıcl, Tahsin: "Haydar, Kutbüddin", Türkiye Diyanet Vakfı Islam Ansiklopedisi (DIA), 1998, XVII, s. 24-25.

Yılmaz, Hakan: “Geyikli Baba'nın İnegöl'e Yerleşmesi, Orhan Gazi ile İlişkisi ve Heterodoksluğu Yönündeki İddiaların Kesin Deliller Işığında Çürütülmesi", Uluslararası Inegöl Tarihi ve Kültürü Sempozyumu (14-16 Ekim 2016), İstanbul 2017, s. 472-476.

Yücel, Yaşar: Kadı Burhaneddin Ahmed ve Devleti (1344-1398), Ankara: DTCF Yayınları, 1970. 


\section{EKLER}

\section{EK - 1: VGMA, D. 1966, s. 1-4/1-4. Şeyh Edhem Bayezidiyye Hanikâhı Vakfı}

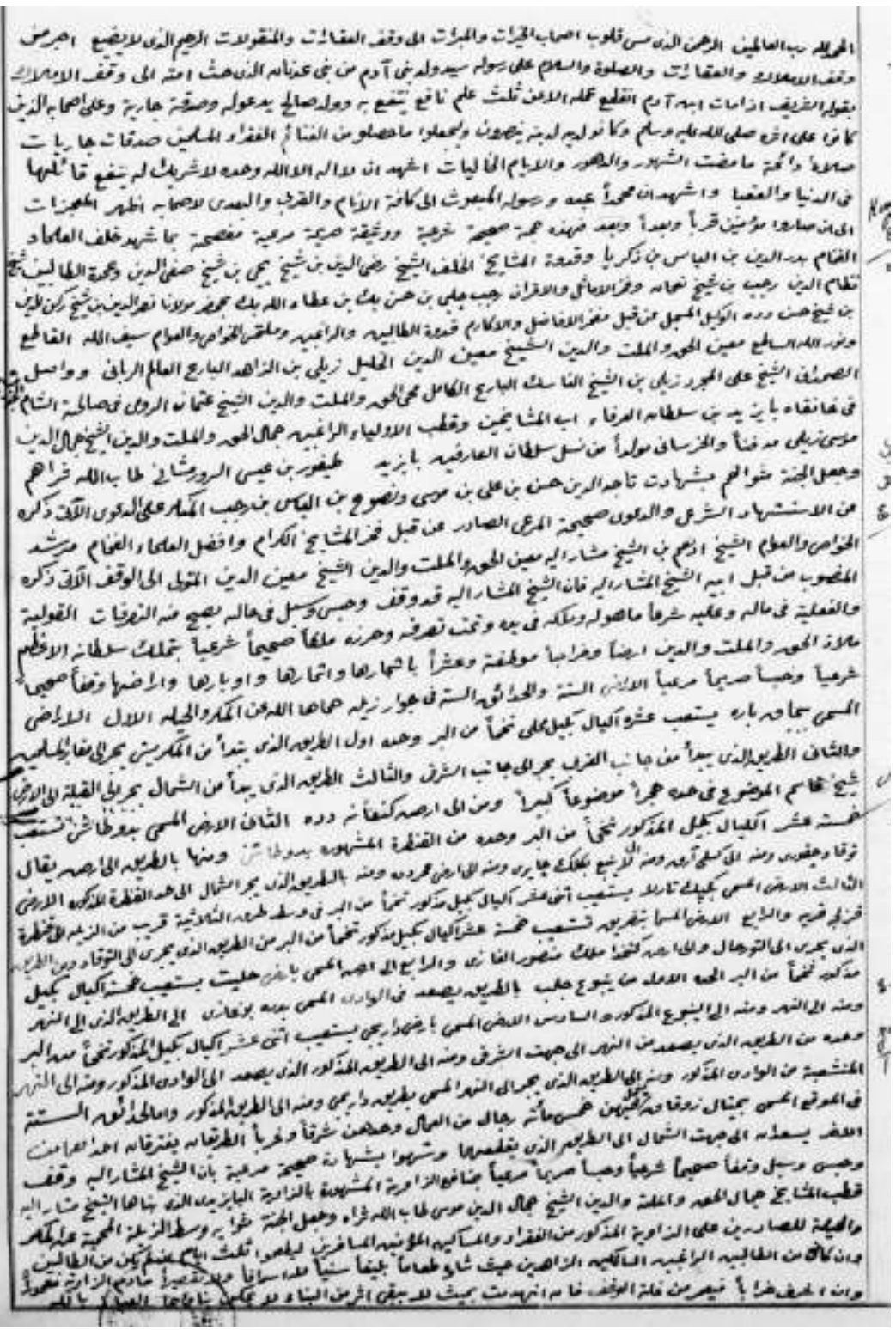

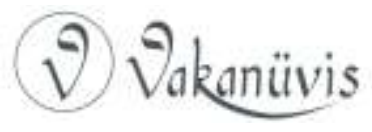




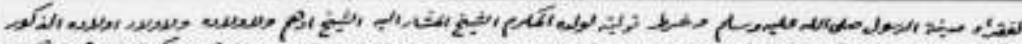

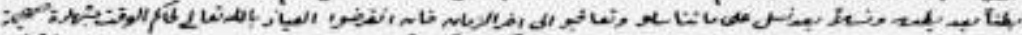

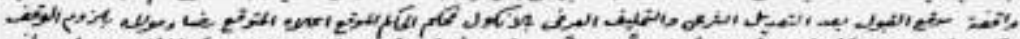

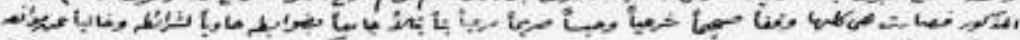

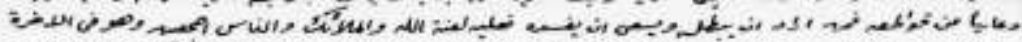
مال

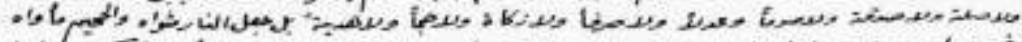

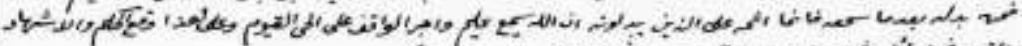
ing 年

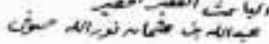
rkm $\cos 6 \sin 4=2 \times$

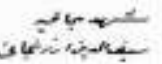

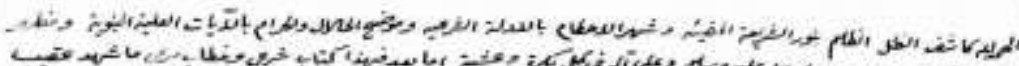

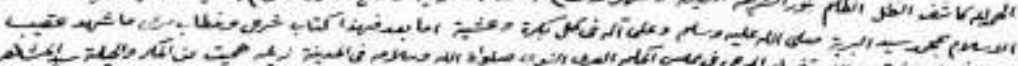

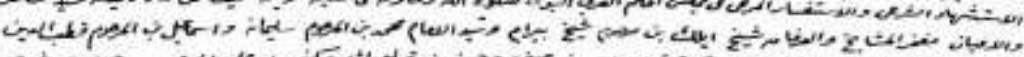

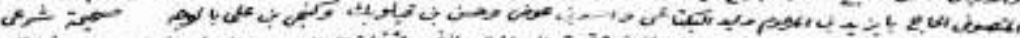

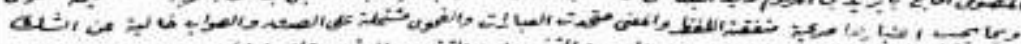

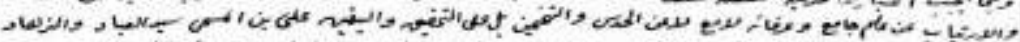

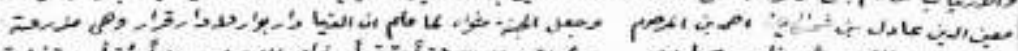

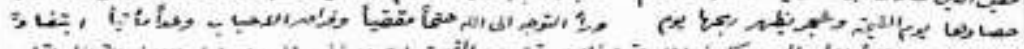

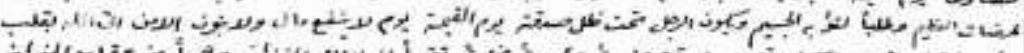
年

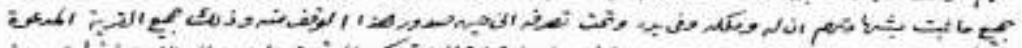

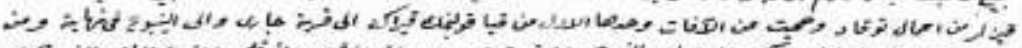

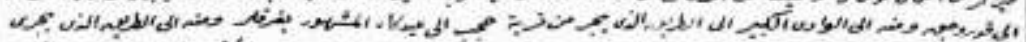

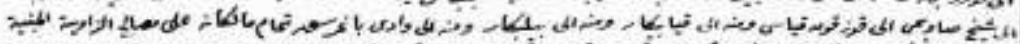

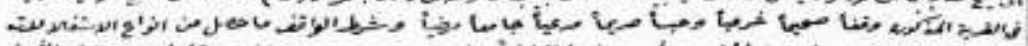

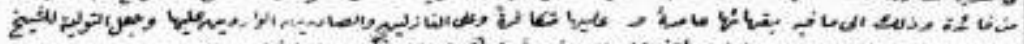

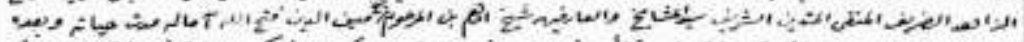

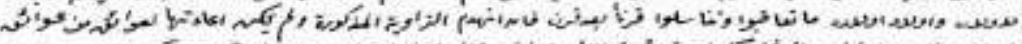

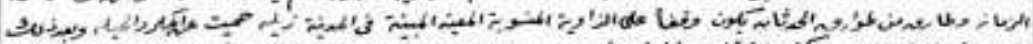

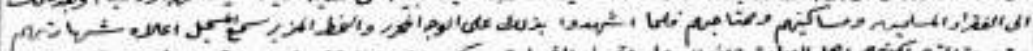
رتt حلإبه

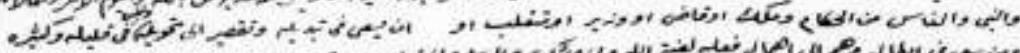

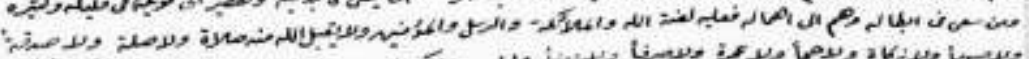

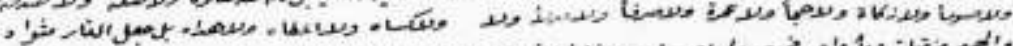

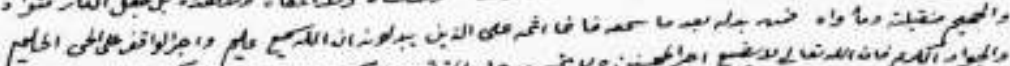
st

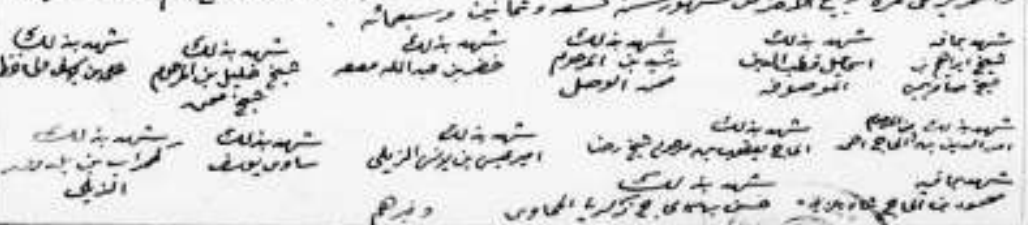




\section{3}

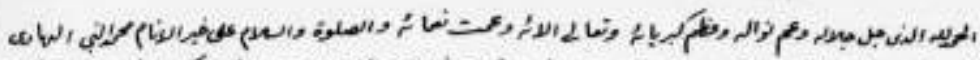

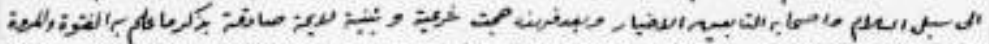

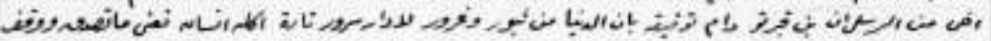

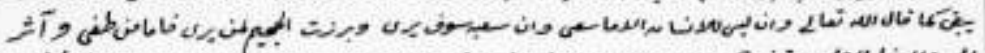

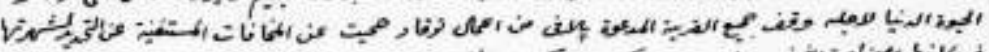

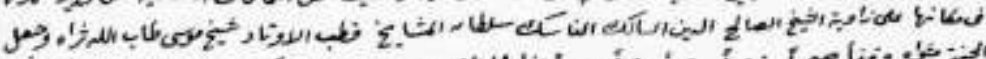

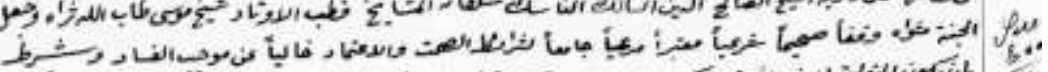

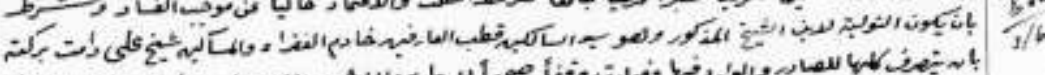

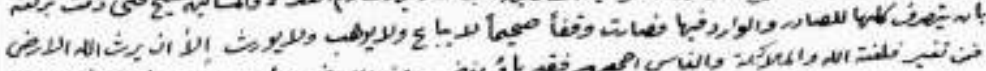

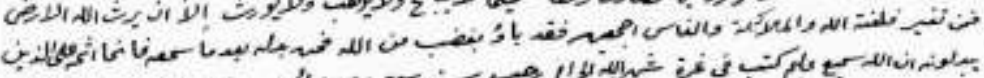

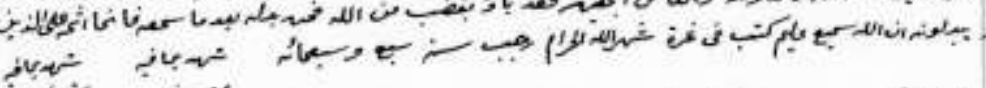
"था

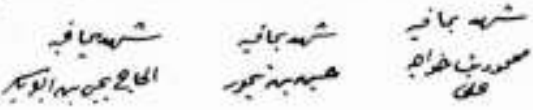

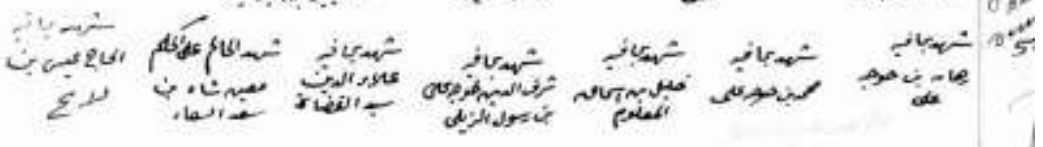

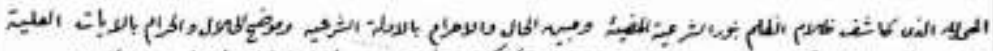

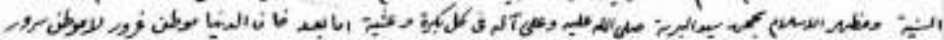

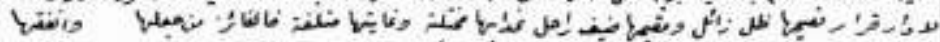

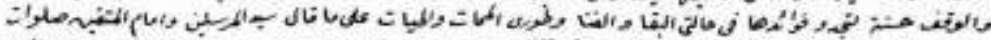

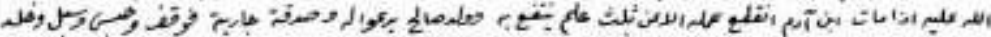

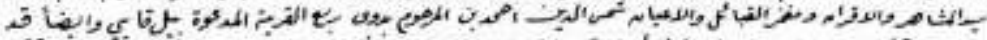

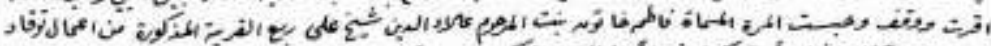

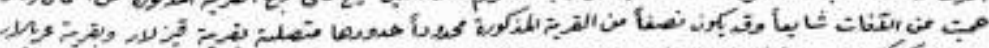

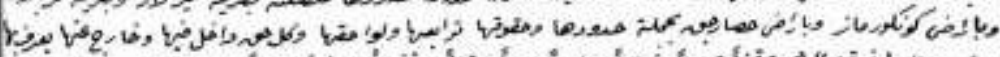

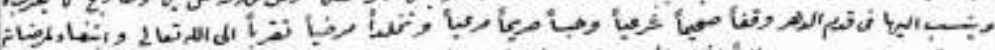

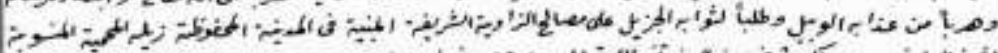

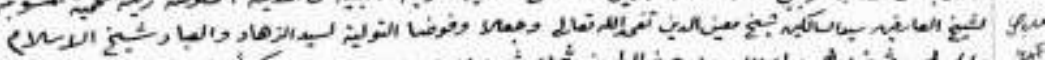

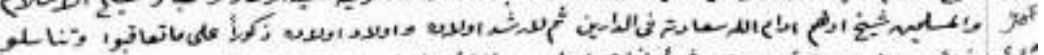
吾

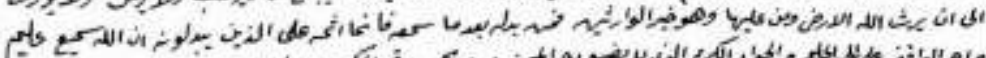

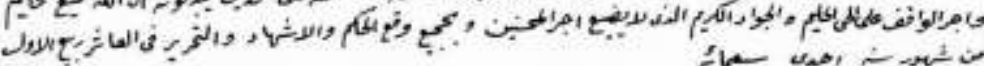

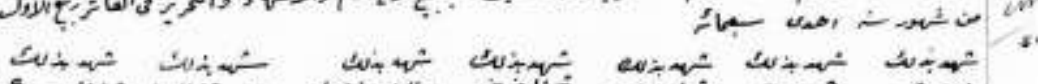

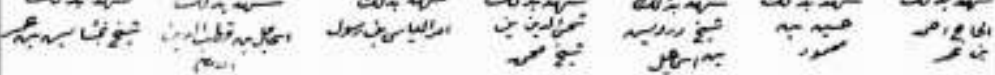


Ek - 2: Süleymaniye Kütüphanesi, Halet Efendi Kol. 92-1. Menâhici Seyfi.

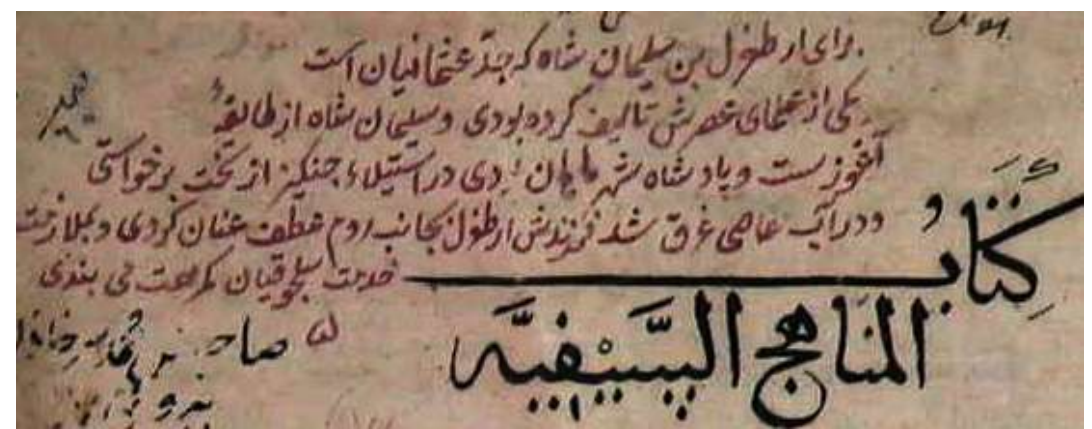

Ek - 3: BOA. TD. 75, s. 537-539. Karaca Ahmed ve Ahi Musa Zaviyeleri

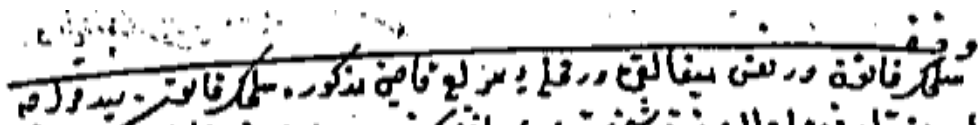

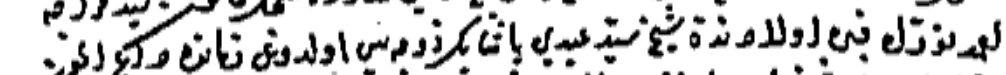

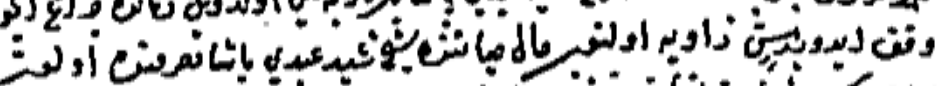

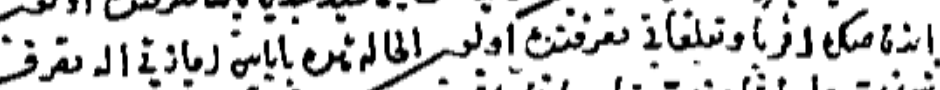

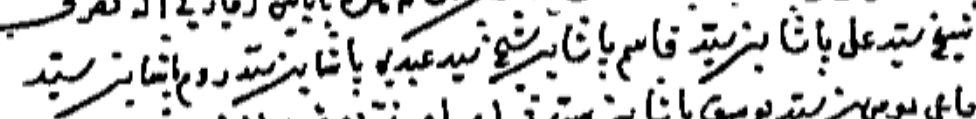

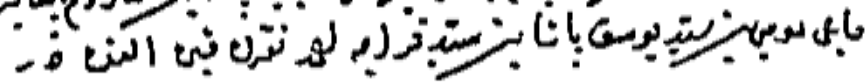

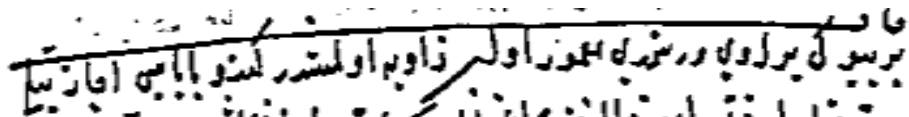

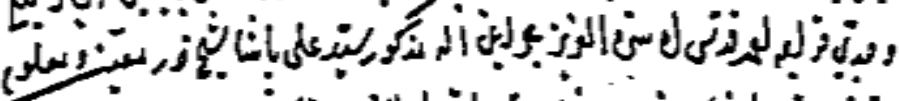

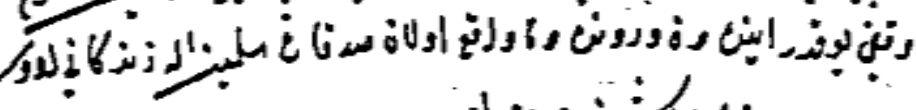

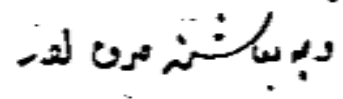




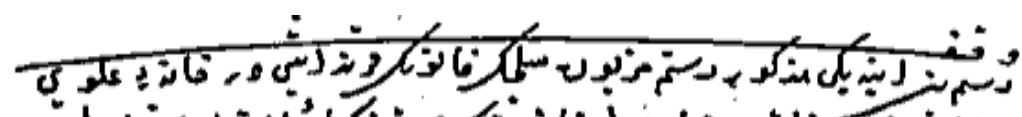

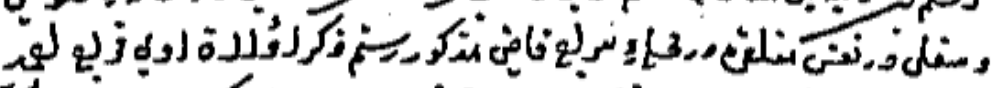

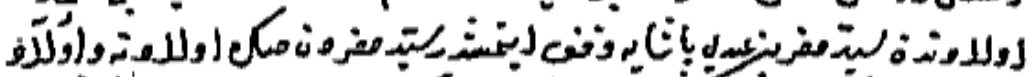

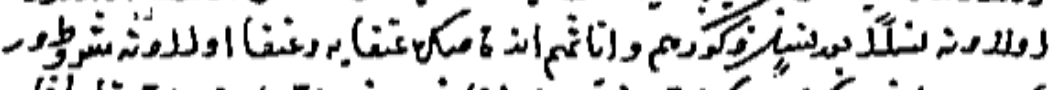

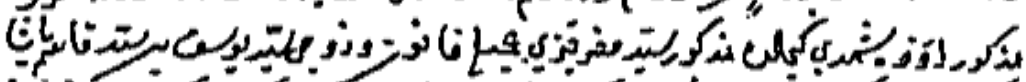

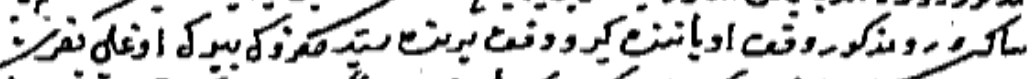

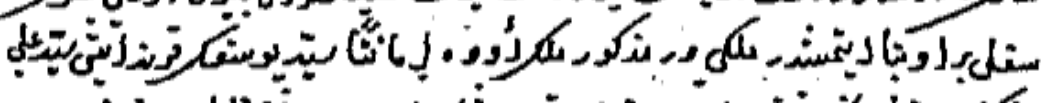

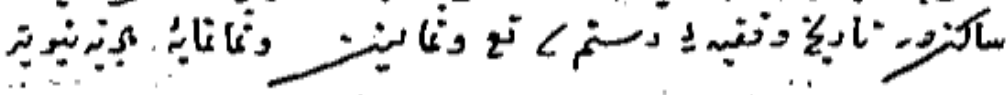

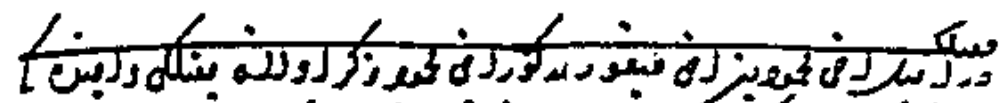

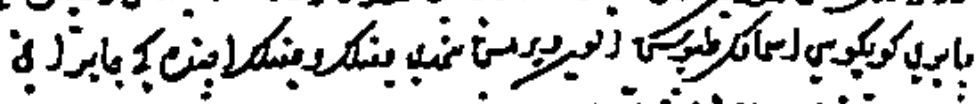

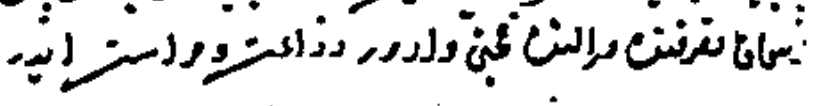

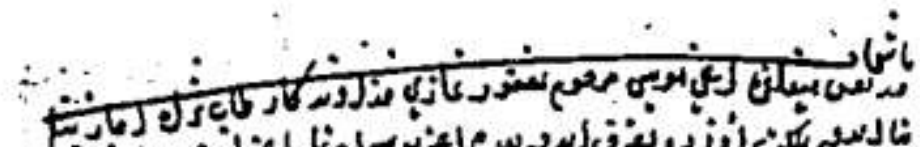

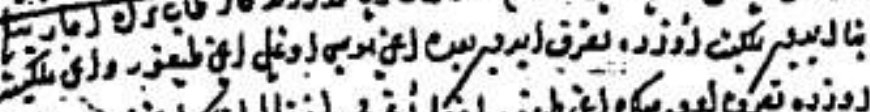

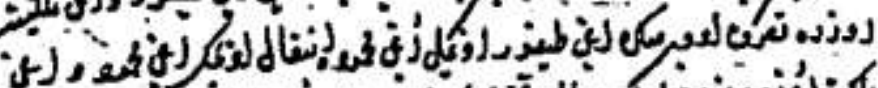

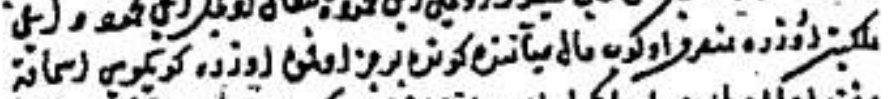

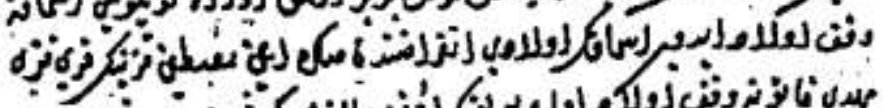

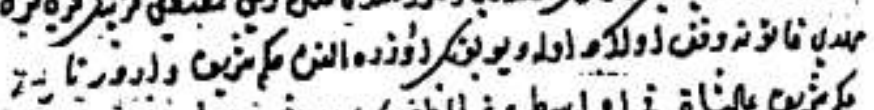

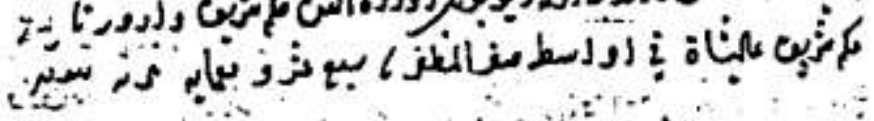




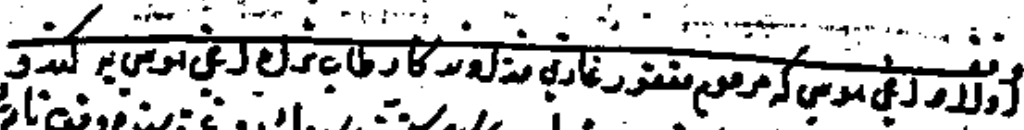

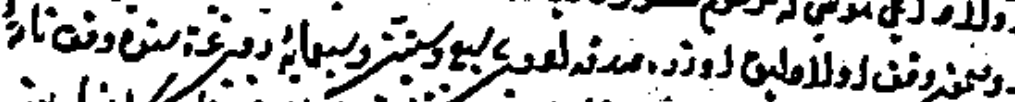

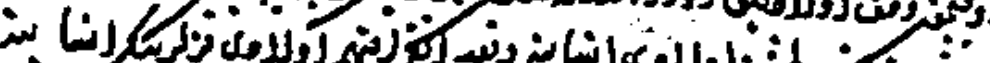

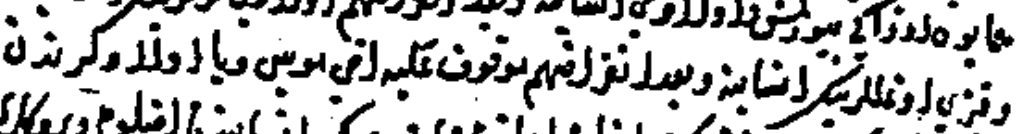

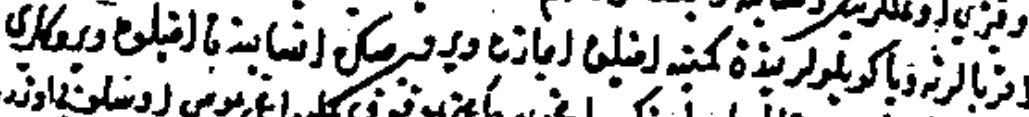

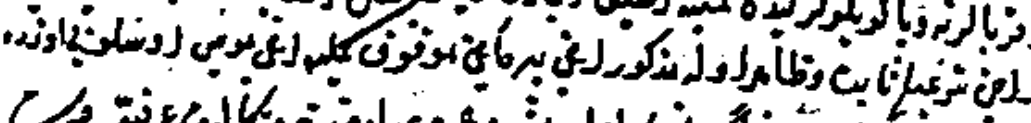

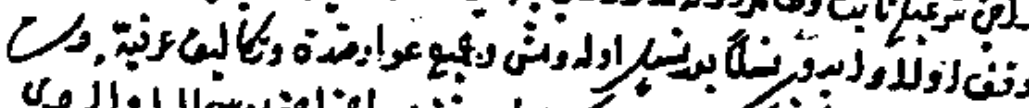

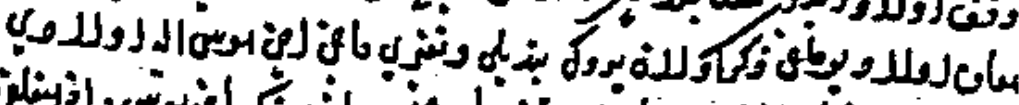

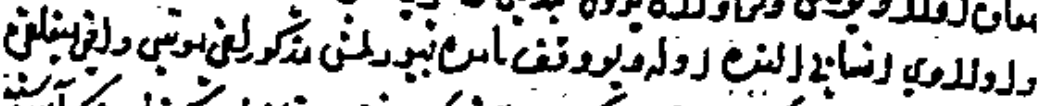

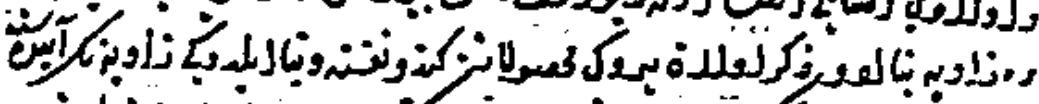

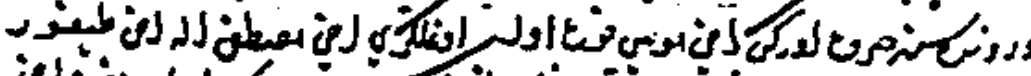

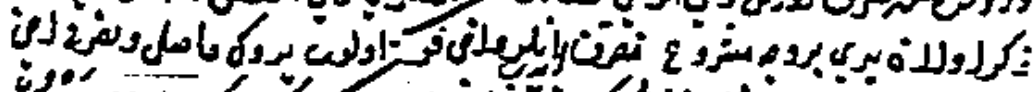

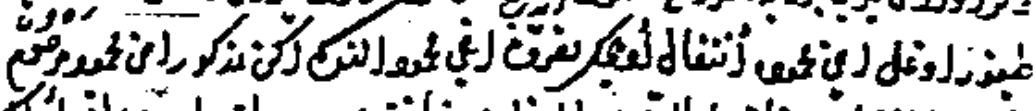

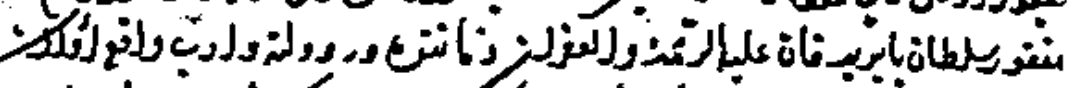

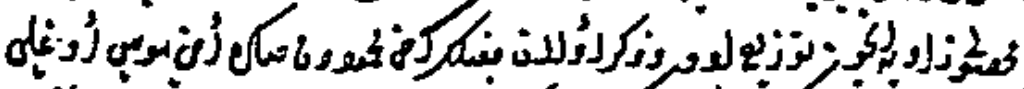

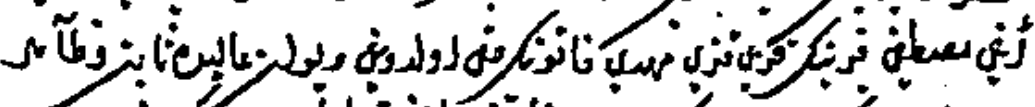

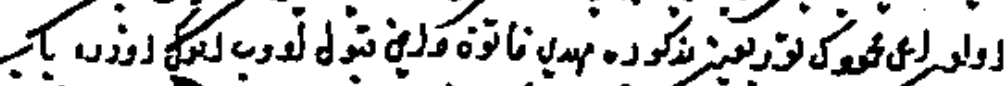

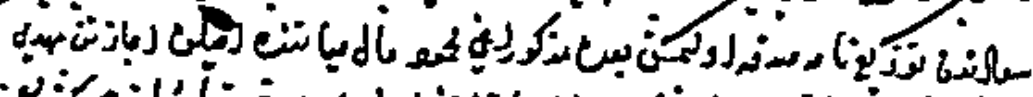

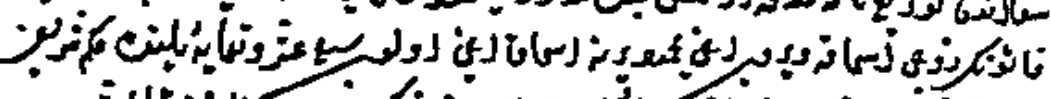

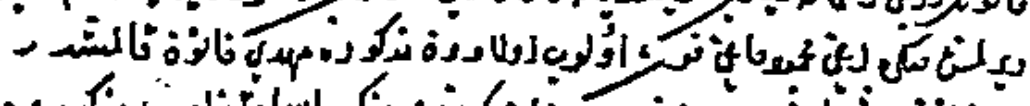

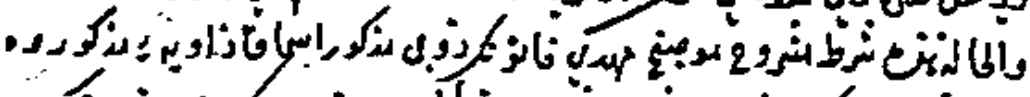

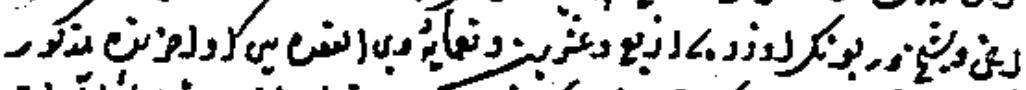

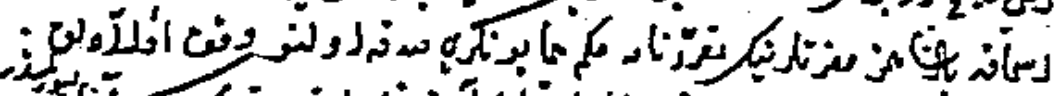

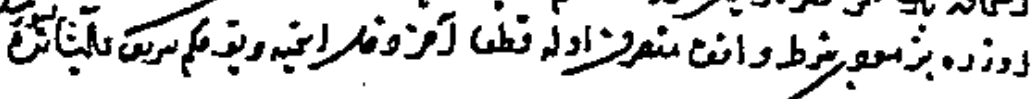

\section{(D) Vakaniuis}


Ek - 4: TADB. TTD. EV. 554, v. 25a. Tay Sultan Zaviyesi

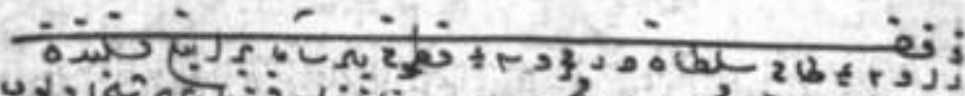

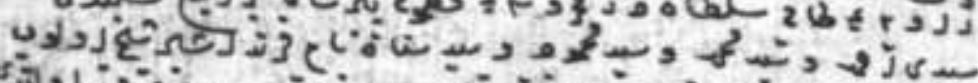

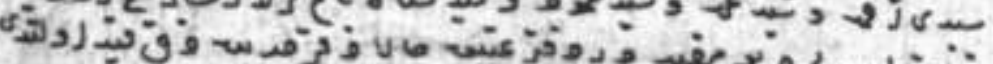
ن

Ek - 5: TADB. TTD. EV. 560, v. 187a. Karaca Ahmed Zaviyesi

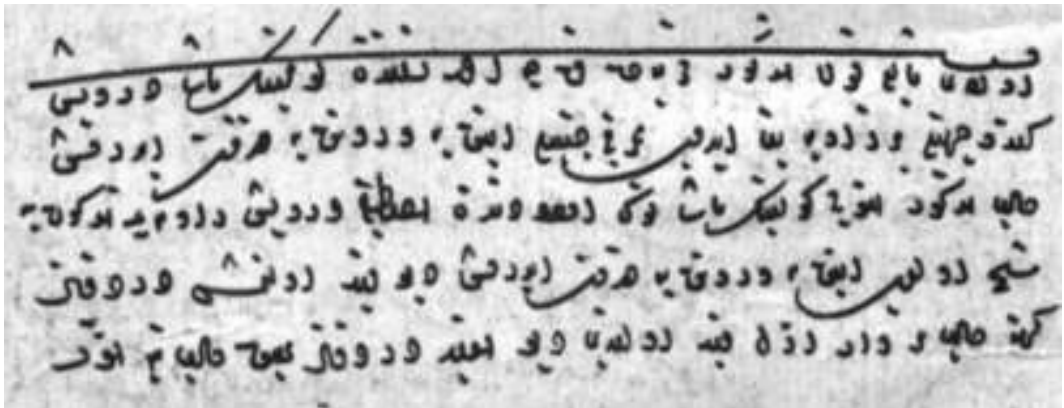

Ek - 6: TADB. TTD. EV. 579, v. 117b. Emirce Sultan Vakfı

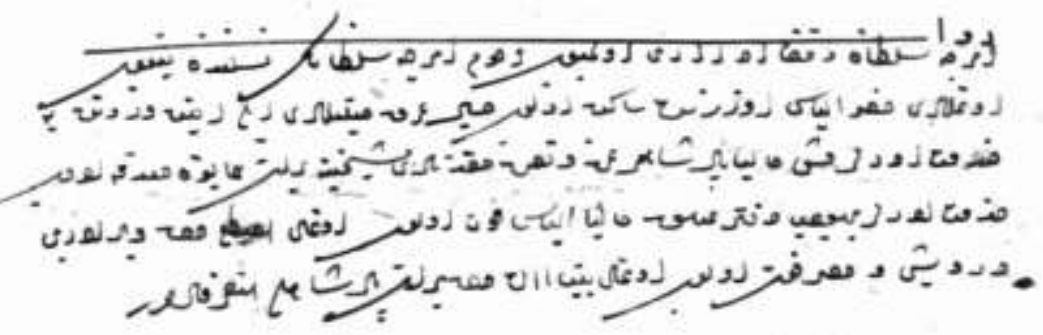

Ek - 7: TADB. TTD. EV. 555, v. 169b. Ahi Tayî-Ahi Kâmil Zaviyesi

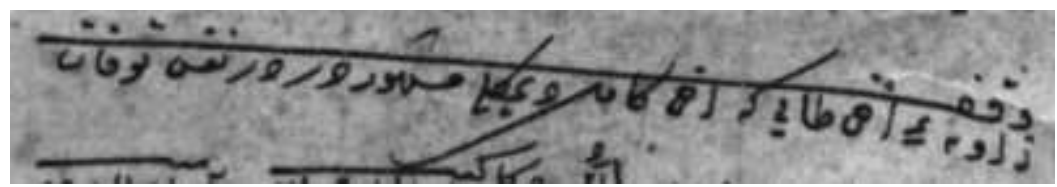

\section{(V) Vakanüvis}

